\title{
Variations in mineralogy of dust in an ice core obtained from northwestern Greenland over the past 100 years
}

\author{
Naoko Nagatsuka ${ }^{1}$, Kumiko Goto-Azuma ${ }^{1,2}$, Akane Tsushima ${ }^{3}$, Koji Fujita $^{4}$, Sumito Matoba ${ }^{5}$, Yukihiko Onuma ${ }^{6}$, \\ Remi Dallmayr $^{7}$, Moe Kadota ${ }^{5,8}$, Motohiro Hirabayashi ${ }^{1}$, Jun Ogata $^{1}$, Yoshimi Ogawa-Tsukagawa ${ }^{1}$, \\ Kyotaro Kitamura $^{1}$, Masahiro Minowa ${ }^{4}$, Yuki Komuro ${ }^{1}$, Hideaki Motoyama ${ }^{1,2}$, and Teruo Aoki ${ }^{1,2}$ \\ ${ }^{1}$ National Institute of Polar Research, Tokyo 190-8518, Japan \\ ${ }^{2}$ Department of Polar Science, The Graduate University for Advanced Studies, SOKENDAI, Tokyo 190-8518, Japan \\ ${ }^{3}$ Graduate School of Science, Chiba University, Chiba 277-0882, Japan \\ ${ }^{4}$ Graduate School of Environmental Studies, Nagoya University, Nagoya 464-8601, Japan \\ ${ }^{5}$ Institute of Low Temperature Science, Hokkaido University, Sapporo 060-0819, Japan \\ ${ }^{6}$ Institute of Industrial Science, University of Tokyo, Kashiwa 277-8574, Japan \\ ${ }^{7}$ Alfred Wegener Institute, Am Alten Hafen 26, 27568 Bremerhaven, Germany \\ ${ }^{8}$ Graduate School of Environmental Science, Hokkaido University, Sapporo 060-0810, Japan
}

Correspondence: Naoko Nagatsuka (nagatsuka.naoko@nipr.ac.jp)

Received: 16 November 2020 - Discussion started: 3 December 2020

Revised: 25 March 2021 - Accepted: 14 April 2021 - Published: 21 June 2021

\begin{abstract}
Our study is the first to demonstrate a hightemporal-resolution record of mineral composition in a Greenland ice core over the past 100 years. To reconstruct past variations in the sources and transportation processes of mineral dust in northwestern Greenland, we analysed the morphology and mineralogical composition of dust in the SIGMA-D ice core from 1915 to 2013 using scanning electron microscopy (SEM) and energy-dispersive X-ray spectroscopy (EDS). The results revealed that the ice core dust consisted mainly of silicate minerals and that the composition varied substantially on multi-decadal and inter-decadal scales, suggesting that the ice core minerals originated from different geological sources in different periods during the past 100 years. The multi-decadal variation trend differed among mineral types. Kaolinite, which generally formed in warm and humid climatic zones, was abundant in colder periods (1950-2004), whereas mica, chlorite, feldspars, mafic minerals, and quartz, which formed in arid, high-latitude, and local areas, were abundant in warmer periods (1915-1949 and 2005-2013). Comparison to Greenland surface temperature records indicates that multi-decadal variation in the relative abundance of these minerals was likely affected by local temperature changes in Greenland. Trajectory analysis shows that the minerals were transported mainly from the west-
\end{abstract}

ern coast of Greenland in the two warming periods, which was likely due to an increase in dust sourced from local icefree areas as a result of shorter snow/ice cover duration in the Greenland coastal region during the melt season caused by recent warming. Meanwhile, ancient deposits in northern Canada, which were formed in past warmer climates, seem to be the best candidate during the colder period (1950-2004). Our results suggest that SEM-EDS analysis can detect variations in ice core dust sources during recent periods of low dust concentration.

\section{Introduction}

Aeolian mineral dust in snow and ice on ice sheets provides key information about global and local climate change. Past ice core dust records have revealed substantial variations in the concentration, composition, particle size, and morphology of minerals on glacial-interglacial timescales (ca. $800 \mathrm{kyr}$ BP; e.g. Petit et al., 1990; Lambert et al., 2008), geologic timescales (from the Eemian to the Holocene; e.g. Maggi, 1997; Ram and Koenig, 1997; Steffensen, 1997; Ruth et al., 2003; Schüpbach et al., 2018; Simonsen et al., 2019), and seasonal scales (e.g. Bory et al., 2003a; Drab et al., 2002). Ice core dust records show a close relation- 
ship with temperature changes and atmospheric circulation. Dust concentrations in Greenland ice cores during the last glacial period were 10 to 100 times higher than those over the Holocene and were strongly correlated with temperature changes (as indicated by $\delta^{18} \mathrm{O}$ records; e.g. De Angelis et al., 1997; Mayewski et al., 1997; Fuhrer et al., 1999; Ruth et al., 2003; Schüpbach et al., 2018). Steffensen (1997) also showed a systematic connection between dust volume distribution, total dust mass, and $\delta^{18} \mathrm{O}$ in the Greenland Ice Core Project (GRIP) ice core, indicating that climate changes appear to have modified the processes of formation, transport, and deposition of mineral dust in the same way over the last 120000 years. Meanwhile, there is a significant correlation between the dust flux of the European Project for Ice Coring in Antarctica (EPICA) ice core with Antarctic temperature during glacial periods, but not during interglacial periods, suggesting that the conditions of source areas and the transport of ice core dust change according to the glacialinterglacial cycle (Lambert et al., 2008). The variability of ice core dust may be related to changes in atmospheric transport and dust source areas affected by climate change (Svensson et al., 2000). Thus, it is important to reconstruct the variations in the sources and transportation processes of mineral dust in ice cores.

Geochemical analyses, such as stable isotope ratios of $\mathrm{Sr}$, $\mathrm{Nd}$, and $\mathrm{Pb}$, have been used to identify possible sources of Greenland ice core dust. These isotopic ratios have strong regional variations that are controlled by their geological origins and are hardly altered during transportation in the atmosphere or after deposition (Capo et al., 1998; Faure and Mensing, 2004). The isotope ratios of the GRIP and Greenland Ice Sheet Project 2 (GISP2) ice core dust obtained from 44 to $12 \mathrm{kyr}$ BP indicated that eastern Asian deserts appeared to be the most likely dust sources (Biscaye et al., 1997; Svensson et al., 2000) and that central/east central European loess might also be a major source of dust in the last glacial ice core (Újvári et al., 2015). Lupker et al. (2010) analysed the $\mathrm{Sr}$ and $\mathrm{Nd}$ isotopic ratios of mineral dust in an ice core from southern Greenland (Dye 3) in the age range of 1786$1793 \mathrm{CE}$ and revealed that the Sahara might be an additional dust source. Han et al. (2018) showed temporal variations in the source areas of the NEEM ice core dust based on $\mathrm{Sr}$ and $\mathrm{Pb}$ isotope analysis; the primary dust source was eastern Asian deserts from 31 to $23 \mathrm{kyr}$ and the Sahara from 23 to $12 \mathrm{kyr}$. However, these analyses have targeted mostly ice core dust from glacial periods characterized by a high dust concentration because $\mathrm{Sr}$ and $\mathrm{Nd}$ isotopic ratio analyses need large numbers of samples. Although some studies have analysed the $\mathrm{Sr}$ and $\mathrm{Nd}$ isotopes of ice core minerals during the Holocene, a recent period of low dust concentration, they needed to concentrate decades to thousands of years of ice for each sample (e.g. Bory et al., 2003a; Han et al., 2018; Simonsen et al., 2019). Thus, there is limited information about possible sources of mineral dust in interglacial periods during which dust concentrations are low.
Scanning electron microscopy (SEM) and energydispersive X-ray spectroscopy (EDS) are useful tools for revealing the source areas of ice core dust samples with low amounts of mineral dust. SEM provides morphological information, and EDS provides the mineralogical composition of individual particles, allowing the evaluation of the continental dust input and showing variations in ice core dust properties. Donarummo et al. (2003) analysed the size distribution and mineral composition of GISP2 ice core dust during the 1930s by SEM-EDS and suggested that the central United States might have contributed a substantial amount of minerals to the ice core when the source area was affected by intense droughts. The SEM-EDS analysis of dust from snow pit samples from 1989 to 1991 at Summit in central Greenland indicated that the possible sources were likely to be Asian deserts, and the source areas have not changed seasonally (Drab et al., 2002). Therefore, SEM-EDS analysis can demonstrate a high-temporal-resolution record of composition and sources of ice core minerals during interglacial periods. However, continuous variations in the dust properties of Greenland ice cores during recent years are still not well known.

Possible source areas for the Greenland ice core dust may have varied in recent years. Most of the Earth's surface has changed rapidly because of recent climate warming and human activities, which may result in changes in atmospheric transport and sources of mineral dust to the ice sheet. For example, dust outbreaks occurring in eastern Asian deserts, which are vast sources of aeolian mineral dust, remarkably increased from 2000 to 2002 compared with the 1990s (Kurosaki and Mikami, 2003). The dust from Asian deserts is transported to Greenland across the ocean. Zhang et al. (2020) revealed that there has been an abrupt shift toward a hotter and drier climate over east Asia over the past 260 years, according to tree-ring-based reconstructions of heat waves and soil moisture. Furthermore, there may also be an increasing contribution of dust from local source areas in Greenland (Amino et al., 2021). The retreating ice and decreasing seasonal snow will expose more sediment in the proglacial area, delivering greater quantities of fine sediments to the floodplain than at present. Bullard and Austin (2011) reported that exposure of the proglacial floodplain in Kangerlussuaq, western Greenland, during ice retreat may also make more material available for aeolian transport.

This paper aims to describe the temporal variations in sources of minerals in a Greenland ice core covering a nearly 100-year period (1915-2013) with a 5-year resolution, during which the Arctic region was remarkably warming. The morphology and mineralogical composition of the ice core dust were analysed by SEM and EDS, and variations are discussed in terms of changes in the ice core dust sources. 


\section{Samples and analytical methods}

\subsection{SIGMA-D ice core}

The ice core was drilled at $2100 \mathrm{~m}$ a.s.l. in an accumulation area of the northwestern Greenland Ice Sheet called the SIGMA-D site $\left(77.636^{\circ} \mathrm{N}, 59.120^{\circ} \mathrm{W}\right)$ in May 2014 (Matoba et al., 2015). The SIGMA-D site is located $250 \mathrm{~km}$ east of the town of Qaanaaq and lies in the upstream section of Heilprin Glacier, the largest outlet glacier in this area (Fig. 1). The ice core was recovered from the surface down to a depth of $222.72 \mathrm{~m}$ (total core length).

\subsection{Water isotope and ion concentration measurement}

To determine the annual layers of the SIGMA-D ice core, the stable isotopes of water $\left(\delta^{18} \mathrm{O}\right)$ and the concentrations of sodium and sulfate ions $\left(\mathrm{Na}^{+}\right.$and $\left.\mathrm{SO}_{4}^{2-}\right)$ were measured at the Institute of Low Temperature Science, Hokkaido University, and the concentration of tritium was measured at the National Institute of Polar Research (NIPR), Tokyo, Japan.

The ice core samples were cut into $5-10 \mathrm{~cm}$ pieces with cross sections of $30 \mathrm{~cm}^{2}$ and decontaminated by removing the surface of each sample with a ceramic knife. Then, each sample was placed in a clean polyethylene bag and melted in a water bath, before being transferred to pre-cleaned polypropylene bottles in a tent for sample preparation at the field camp (Matoba et al., 2015). $\delta^{18} \mathrm{O}$ was measured using a near-infrared cavity ring-down spectrometer (IR-CRDS, Picarro L2130-i, USA) with a high-throughput Picarro-A0212 vaporizer. The precision of determination was $\pm 0.08 \%$ o for $\delta^{18} \mathrm{O}$. The concentrations of $\mathrm{Na}^{+}$and $\mathrm{SO}_{4}^{2-}$ were determined by ion chromatography (ICS-2100, Thermo Fisher Scientific, USA). Dionex AS-14A and CS-12A columns (Thermo Fisher Scientific) were used for anion and cation analyses, respectively. The limit of quantification was $5 \mathrm{ppb}$ for both ions. For $\mathrm{SO}_{4}^{2-}$, we also calculated its non-sea-salt (nss) fractions as follows:

$\left[\mathrm{nssSO}_{4}^{2-}\right]=\left[\mathrm{SO}_{4}^{2-}\right]-\left(\mathrm{SO}_{4}^{2-} / \mathrm{Na}^{+}\right)_{\text {sea }} \times\left[\mathrm{Na}^{+}\right]$,

where $\left(\mathrm{SO}_{4}^{2-} / \mathrm{Na}^{+}\right)_{\text {sea }}$ is the mass ratio of $\mathrm{SO}_{4}^{2-}$ to $\mathrm{Na}^{+}$in the seawater, which is 0.252 (Wilson, 1975; Legrand and Mayewski, 1997). Tritium concentrations were measured using a liquid scintillation counter (LSC-LB3; Aloka Co. Ltd., Japan). The vertical resolution of the tritium measurements was $0.5 \mathrm{~m}$.

\subsection{Dust concentration}

The concentration of dust in the SIGMA-D ice core was measured using an Abakus laser particle sensor (Klotz GmbH, Germany) connected to a continuous-flow analysis (CFA) system, a slightly modified version of the one reported by Dallmayr et al. (2016). The size bins cover the range from 1.5 to $15.0 \mu \mathrm{m}$, and the depth resolution of the measurement was
$2-3 \mathrm{~cm}$. CFA analysis has not been performed since 2003 (above a depth of $6.35 \mathrm{~m}$ ) due to poor core quality.

\subsection{SEM-EDS analysis of mineral dust}

To extract mineral particles from the ice core at 5-year intervals, $4 \mathrm{~cm}^{2}$ cross sections were cut from the $50 \mathrm{~cm}$ long archived core sections in the $-20^{\circ} \mathrm{C}$ cold room at NIPR. The possibly contaminated outer layers $(\sim 1 \mathrm{~cm}$ thick) were removed using a pre-cleaned ceramic knife. Then, several millimetres of the ice surface was scraped off by the ceramic knife and collected in a clean $100 \mathrm{~mL}$ polyethylene bottle for every 5 -year interval. The samples were freezedried at $-45^{\circ} \mathrm{C}$ using a freeze dryer (DRW240DA; Advantec, Japan) on a polycarbonate membrane filter (Advantec) with a diameter of $25 \mathrm{~mm}$ and pore size of $0.1 \mu \mathrm{m}$. The morphological characteristics and chemical composition of individual mineral particles on the membrane filter were observed by SEM (Quanta FEG 450, FEI) combined with EDS (X-Max 50, Oxford Instruments, UK) at NIPR. The filter targets were mounted on aluminium stubs using double-faced adhesive carbon tape and coated with vaporized platinum for SEM observation. In total, 150 particles were randomly chosen from the filter, and the equivalent circle diameter, the two-dimensional area $(A)$, and the perimeter $(P)$ were measured on digital photographs with an image-processing application (ImageJ, National Institutes of Health, USA). Then, the shape parameters of the particles were obtained, namely circularity $\left(=(4 \pi A) \times P^{-2}\right)$. The major elemental composition ( $\mathrm{Na}, \mathrm{Mg}, \mathrm{Al}, \mathrm{Si}, \mathrm{Cl}, \mathrm{S}, \mathrm{Ca}, \mathrm{K}, \mathrm{Fe}, \mathrm{P}$, and $\mathrm{Ti}$ ) and related oxides $\left(\mathrm{Na}_{2} \mathrm{O}, \mathrm{MgO}, \mathrm{Al}_{2} \mathrm{O}_{3}, \mathrm{SiO}_{2}, \mathrm{CaO}, \mathrm{K}_{2} \mathrm{O}, \mathrm{Fe}_{2} \mathrm{O}_{3}, \mathrm{P}_{2} \mathrm{O}_{5}\right.$, and $\mathrm{TiO}_{2}$ ) were obtained from the EDS spectra. The acceleration voltage and working distance for SEM analysis were $20 \mathrm{kV}$ and $10 \mathrm{~mm}$, respectively, and each EDS spectrum had more than 100000 acquisition counts. To be counted as a mineral dust, a particle had to contain at least one of the elements $\mathrm{Na}, \mathrm{Mg}, \mathrm{Si}, \mathrm{Al}, \mathrm{K}, \mathrm{Ca}$, and $\mathrm{Fe}$, each with an atomic ratio (\%) amount at least twice that of the error (\%). We did not count soluble particles, such as $\mathrm{CaSO}_{4}, \mathrm{Na}_{2} \mathrm{SO}_{4}$, and $\mathrm{NaCl}$, that can be derived from volcanic and marine aerosols.

\subsection{Mineral identification}

The mineralogical identification was performed using elemental composition and related oxides of individual mineral particles. Previous studies used protocols to semiquantitatively identify the mineralogy of individual particles in ice cores by SEM-EDS analysis (e.g. Mudroch et al., 1977; Maggi, 1997; Donarummo et al., 2003; Wu et al., 2016). The identification of the SIGMA-D ice core dust followed three procedures (Wu et al., 2016). First, the spectrum pattern of each particle was matched to those of standard minerals (Severin, 2004). Second, we compared the oxide composition and morphology of the ice core dust with those of the standard minerals. Finally, a sorting scheme used 


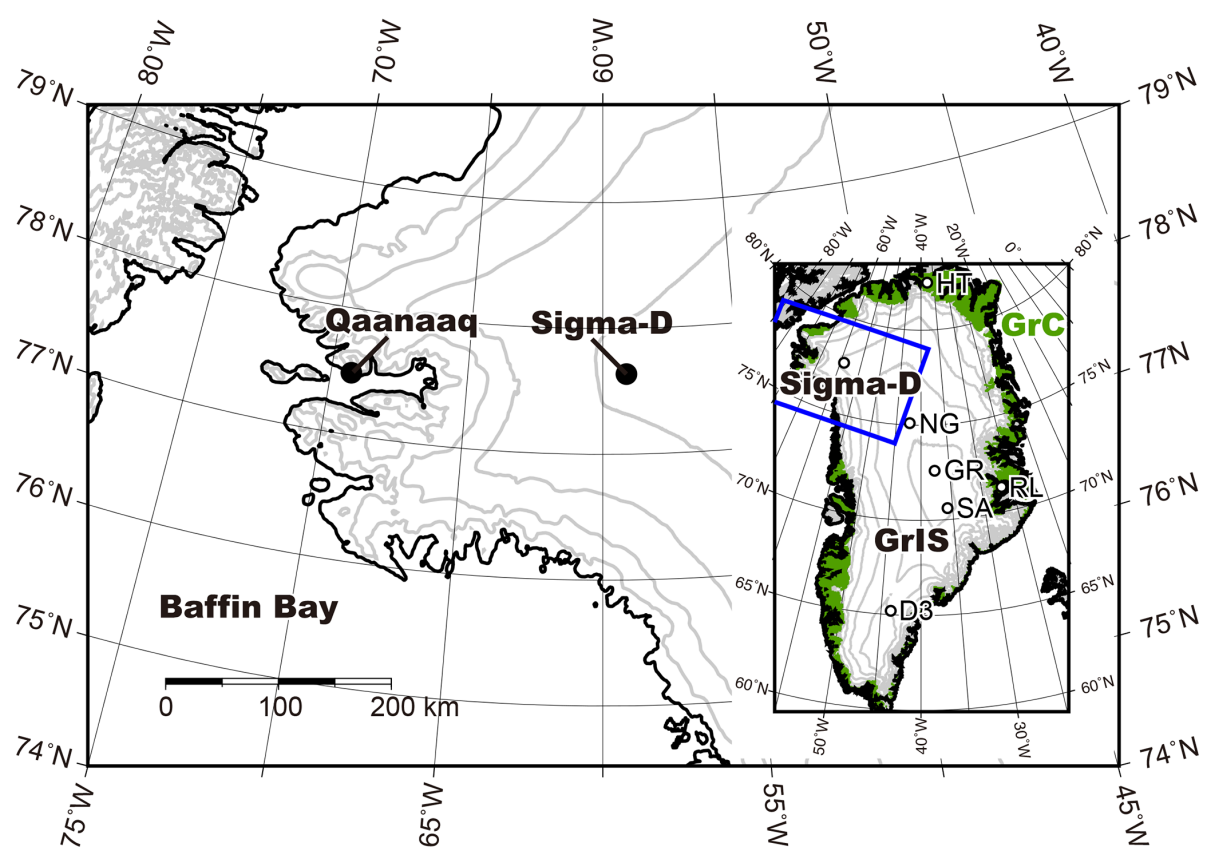

Figure 1. Location map of the SIGMA-D site $\left(77.636^{\circ} \mathrm{N}, 59.120^{\circ} \mathrm{W}, 2100 \mathrm{~m}\right.$ a.s.1.). Contour lines are drawn at a $500 \mathrm{~m}$ interval. The blue frame in the inset map of Greenland (GrIS) denotes the domain of the main map. The green shaded region in the inset map denotes the ice-free coastal terrain (GrC), and HT, NG, GR, RL, SA, and D3 denote Hans Tausen, NGRIP, GRIP, Renland, Site-A, and Dye-3 ice core sites for the back-trajectory comparison, respectively.

to identify minerals in the GISP2 Greenland ice core dust by SEM-EDS was applied to identify the mineral types from the peak intensity ratios (Donarummo et al., 2003). Comparing the results of these procedures enables reliable mineral identification (Maggi, 1997; Wu et al., 2016).

Based on the formation process (weathering types), formation environment (temperature and humidity), and possible sources of the SIGMA-D ice core dust, most of the silicates we analysed could be classified into the following five types. Type A consists primarily of kaolinite, which is a clay mineral generally formed by chemical weathering in warm and humid regions, including Africa, South America, and Southeast Asia (e.g. Mueller and Bocquier, 1986; Velde, 1995; Bergaya et al., 2006). We also found a mineral composed of $\mathrm{Si}$ and $\mathrm{Al}$, but with a higher proportion of $\mathrm{Si}$ and a lower proportion of $\mathrm{Al}$ compared with kaolinite. It is likely pyrophyllite, which is generally found with kaolinite, and is thus also classified as Type A. Type B comprises mica, chlorite, and a mixture of the two, which are clay minerals formed by mechanical weathering of igneous and metamorphic rocks in cold and dry regions (e.g. Cremaschi, 1987; Pye, 1987; Velde, 1995). Type C consists of feldspars (Na/Ca- and Kfeldspars), which are also formed by mechanical weathering in cold and dry regions (e.g. Nahon, 1991). Type D consists of mafic minerals containing abundant $\mathrm{Mg}$ and $\mathrm{Fe}$, such as hornblende and pyroxene, which are less frequent in atmospheric dust and are formed by mechanical weathering (e.g. Deer et al., 1993). Type E consists of quartz, which are the most physically and chemically resistant minerals to weathering, and their abundance in the atmosphere is related to the large desert source areas (Pye, 1987; Yokoo et al., 2004; Genthon and Armengaud, 1995). According to previous studies, some minerals have localized distributions. Ito and Wagai (2017) showed the global terrestrial distribution of clay size mineral groups, revealing that Type A minerals were predominant in humid regions in low- or middle-latitude areas, whereas Type B minerals were abundant in arid and/or highlatitude areas. Furthermore, kaolinite (Type A) can be used as an indicator of intensive weathering in palaeoclimatic conditions (Biscaye, 1965; Griffin et al., 1968). For example, the relative abundance of kaolinite (Type A) to chlorite (Type B) is a mineral indicator that is most sensitive to latitude dependency. The kaolinite / chlorite ratio shows higher values for minerals from low latitudes, such as North Africa, but showed lower values for minerals from the Northern Hemisphere, such as Asia and North America (e.g. Biscaye et al., 1997; Maggi, 1997; Svensson et al., 2000; Donarummo et al., 2003). This trend reflects a decrease in weathering intensity with latitude. In addition to variations in kaolinite and chlorite, Type C, D, and E minerals also reflect the geological and climatic conditions of their source areas, as mentioned above. Thus, compositional variations among the five types of minerals can be used as an indicator of the source and transportation process of ice core dust in different periods. In this study, we consider each type of mineral as possibly being contributed from the following sources: Type A, 
low- to mid-latitude areas (e.g. central Africa, South America, and Southeast Asia); Types B and C, high-latitude (e.g. North America, Russia, north Europe, and Greenland) and/or desert areas (e.g. Asia and North Africa); Type D, local areas (Greenland); and Type E, desert areas (e.g. Asia and North Africa).

\subsection{Backward trajectory analysis}

To investigate the possible source regions of the ice core dust, the air mass transport pathways were analysed using the Hybrid Single-Particle Lagrangian Integrated Trajectory (HYSPLIT) model, which is distributed by the National Oceanographic and Atmospheric Administration (NOAA; Stein et al., 2015). Points at 50, 500,1000, and $1500 \mathrm{~m}$ above ground level (a.g.l.) at the SIGMA-D site were set as the initial points of an air mass for the $7 \mathrm{~d}$ backward trajectories. The probability distribution of the air mass at altitudes below $1500 \mathrm{~m}$ a.g.l. was calculated at a $1^{\circ}$ resolution. We assumed wet and dry deposition processes for the preserved aerosol tracers (Iizuka et al., 2018; Parvin et al., 2019). For wet deposition, the probability was weighted by the daily precipitation when the air mass arrived at the ice core site. For dry deposition, the probability was based on the counting of non-precipitation days when the air mass arrived. We used daily precipitation from the ERA-40 and ERA-Interim reanalysis datasets, both of which were produced by the European Centre for Medium-Range Weather Forecasts (Dee et al., 2011; Uppala et al., 2005). The daily precipitation of ERA-40 $\left(p_{40}\right)$ was calibrated with that of ERA-Interim $\left(p_{\text {int }}\right)$ via linear regression obtained for the period 1979-2001 ( $p_{\text {int }}=0.47 p_{40}, R^{2}=0.702, p<0.001$ ) to maintain consistency between the two precipitation datasets for the entire period (1958-2013). We also calculated the regional contribution from the probability distribution, for which land regions were divided into the following five regions: the Greenland Ice Sheet, the Greenland coast, Canada (including Alaska), northern Eurasia, and mid-latitude arid regions (consisting of China, Central Asia, and the Middle East) (Fig. 2a).

To compare the sources of mineral dust in the Greenland Ice Sheet, the air mass transport pathways were analysed not only from the SIGMA-D site, but also from the other six Greenland ice core sites for which Bory et al. (2003b) revealed the dust sources based on $\mathrm{Sr}$ and $\mathrm{Nd}$ isotope ratios; the four interior sites (NGRIP, GRIP, Site-A, and Dye-3) contain more dust from eastern Asian deserts compared with the two coastal sites (Hans Tausen and Renland). We analysed the $7 \mathrm{~d}$ back trajectories of the air masses for 1981-2010 with an initial height of 500 and $1500 \mathrm{~m}$ a.g.l. at the ice core sites.

\subsection{Snow cover fraction}

To examine the surface conditions of neighbouring source areas of mineral dust, we analysed inter-annual changes in snow cover fraction derived from multiple numerical simu- lations by a climate model. Various international organizations have used global climate models to conduct numerical simulations that reproduce or predict climate change from past to future. The results have been published by Coupled Model Intercomparison Project Phase 6 (CMIP6; Eyring et al., 2016) under the auspices of the World Climate Research Programme. In the present study, snow cover fractions derived from historical simulations for the period 1850-2014 (Onuma and Kim, 2020a, b, c, d) were used to examine mineral dust sources for SIGMA-D. The dataset was produced by MIROC6, a climate model developed by a Japanese modelling community (Tatebe et al., 2019). Four reanalysis datasets, namely GSWP3 (Kim, 2017), CRUJRA (Harris, 2019), Princeton (Sheffield et al., 2006), and WFDEI (Weedon et al., 2014) provided the meteorological conditions for the Land Surface, Snow and Soil moisture Model Intercomparison Project (LS3MIP; van den Hurk et al., 2016), which is a sub-project of CMIP6. We obtained data on inter-annual changes in snow cover fraction during summer on the northwest and southwest coasts of Greenland (boundary at $70^{\circ} \mathrm{N}$ ).

\section{Results}

\subsection{Dating of the SIGMA-D ice core}

Dating of the SIGMA-D ice core was performed by annual layer counting of $\delta^{18} \mathrm{O}$ and $\mathrm{Na}^{+}$that showed obvious seasonal variations (Fig. A1). The observed seasonality of chemical components and the water stable isotope ratio in the snowpack and ice cores have previously been reported at various sites on the Greenland Ice Sheet (Whitlow et al., 1992; Legrand and Mayewski, 1997; Kuramoto et al., 2011; Oyabu et al., 2016; Kurosaki et al., 2020). The winter season of the SIGMA-D ice core was defined as the depth at which $\delta^{18} \mathrm{O}$ was at its minimum value and $\mathrm{Na}^{+}$was at its maximum value, and we counted winter season to winter season as 1 year.

Other fixed dates were provided by the tritium profile and $\mathrm{nssSO}_{4}^{2-}$ spikes. A sharp tritium peak at $11.56 \mathrm{~m}$ w.e. corresponds to the H-bomb test in 1963 (Koide et al., 1982, Clausen and Hammer, 1988), indicating an accumulation rate of $0.23 \mathrm{~m}$ w.e. $\mathrm{yr}^{-1}$ from 1963 to 2013 . The large $\mathrm{nssSO}_{4}^{2-}$ peak appearing at $54.17 \mathrm{~m}$ w.e. is assumed to correspond to the eruption of the Laki volcano in 1783 . The $\mathrm{nssSO}_{4}^{2-}$ signal of the 1783 Laki eruption has also been found in other ice cores in Greenland, Arctic Canada, and Svalbard (Clausen and Hammer, 1988; Grumet et al., 1998; Matoba et al., 2002). Similarly, we assume other $\mathrm{nssSO}_{4}^{2-}$ spikes to be the signatures of unknown (1810), Tambora (1816), and Katmai (1912) volcanic eruptions at shallower depths of 47.53, 46.03 , and $23.50 \mathrm{~m}$ w.e., respectively. Comparing the annual layer counting and these reference horizons, we estimate that the ice core dating includes a 1-year error.

As a result of these analyses, we estimate that the upper $112.87 \mathrm{~m}$ ( $86.06 \mathrm{~m}$ w.e.) of the ice core is equivalent to the 

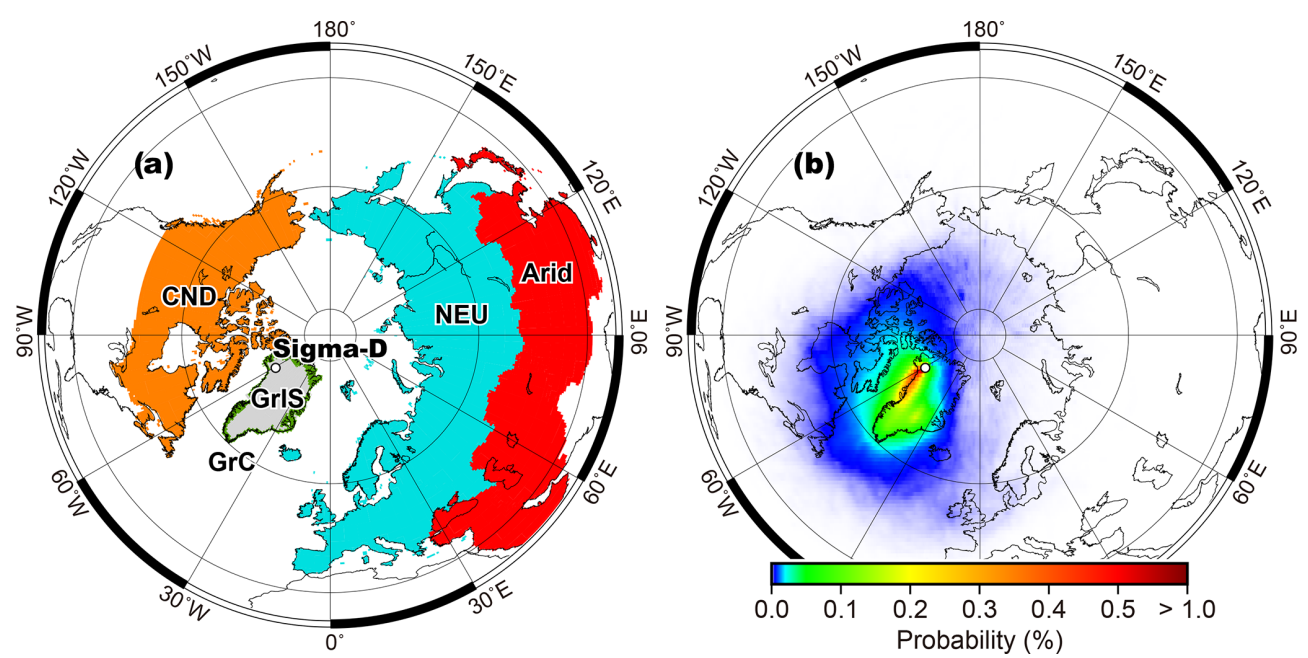

Figure 2. Map showing (a) the location of the SIGMA-D (Sigma-D) ice core site in Greenland and five regions for calculating regional contribution (GrIS: Greenland Ice Sheet, grey; GrC: Greenland coast, green; CND: Canada and Alaska, orange; NEU: northern Eurasia, light blue; Arid: arid regions including China, Central Asia, and the Middle East, red) and (b) the probability distribution of an air mass at the SIGMA-D site from a $7 \mathrm{~d}$ three-dimensional back-trajectory analysis from 1958 to 2014.

period from 1660 to 2013. In this study, we used ice samples to a depth of $38.60 \mathrm{~m}$ ( $22.75 \mathrm{~m}$ w.e.) covering 1915 to 2013 for the SEM and EDS analyses (Table 1).

\subsection{Particle morphology}

Figure 3 shows SEM images of the mineral dust in the SIGMA-D ice core. The number size distribution of mineral dust in the SIGMA-D ice core showed that most particles had a diameter of $<2 \mu \mathrm{m}$ (Fig. 4), which is consistent with other Greenland ice core dust (e.g. Steffensen, 1997; Biscaye et al., 1997). The mean and maximum particle diameters, calculated as 5-year averaged values, ranged from 1.02 to 2.53 and 4.94 to $26.51 \mu \mathrm{m}$, respectively, with a single modal structure at the peak ranging from 0.35 to $1.15 \mu \mathrm{m}$. The size distribution varied among the samples collected from different periods, showing a narrower peak with finer mode (0.35$0.53 \mu \mathrm{m}$ ) for the samples from 1965 to 1979 and a broader peak with a coarser mode for the samples from 1920 to 1924 and 1945 to 1949 (0.97-1.15 $\mu$ m; Fig. A2). There were coarser particles with diameters of $>10 \mu \mathrm{m}$ in the samples from 1915 to 1959 and from 1990 to 2013, but no particles with diameters of $>10 \mu \mathrm{m}$ were found in the samples from 1960 to 1989 , except for the sample from 1980 to 1984.

\subsection{Quantitative estimation of mineral dust}

The elemental composition of individual mineral particles obtained from the EDS analysis showed that the ice core dust was composed mainly of silicate minerals in all the samples $(65 \%-95 \%$, Fig. 6). Based on a peak intensity ratio sorting scheme (Donarummo et al., 2003) and comparison of oxide composition and morphological information with those of standard minerals, the silicates were categorized as quartz, $\mathrm{Na} / \mathrm{Ca}$ - and $\mathrm{K}$-feldspars, clays (kaolinite, pyrophyllite, smectite, illite, mica, and chlorite, as well as mixed layers of illite-smectite and mica-chlorite), and mafic minerals rich in magnesium and iron (Figs. 3 and 7). These minerals were also found in Greenland ice cores from glacial periods (e.g. Maggi, 1997; Svensson et al., 2000).

Semi-quantitative analysis of the EDS spectrum showed that the proportion of kaolinite among 150 mineral particles found in each sample was the highest $(5 \%-66 \%)$ and that of smectite was the lowest $(0 \%-2 \%)$ in nearly every period (Fig. 7 and Table 2). The proportion of pyrophyllite, mica-chlorite mix, quartz, feldspars, and illite-smectite mix was the second highest, varying from $5 \%-27 \%, 3 \%-25 \%$, $3 \%-22 \%, 2 \%-21 \%$, and $2 \%-15 \%$, respectively. The mineralogy of the SIGMA-D ice core dust showed significantly higher kaolinite contents compared with those of the other Greenland ice cores (GRIP, $4 \%-16 \%$, Svensson et al., 2000; GISP2, 0\%-2\%, Donarummo et al., 2003).

The silicate mineral composition showed large variations among the samples on two different timescales. First, the compositions varied on a multi-decadal scale, with higher kaolinite and pyrophyllite contents $(30 \%-66 \%$ and $5 \%-$ $27 \%$ ) and lower mica-chlorite mix contents in the 1950 to 2004 samples ( $3 \%-15 \%$, respectively), especially in the 1975 to 2004 samples. The opposite trend was observed in the 1915 to 1949 and 2005 to 2013 samples (kaolinite and pyrophyllite: $5 \%-20 \%$ and $6 \%-16 \%$, respectively; micachlorite mix: $9 \%-25 \%$ ). The compositional variation also showed higher feldspars, mafic, and quartz contents in the 1915 to 1949 and 1990 to 2013 samples (feldspars: 2\%$21 \%$; mafic: $0 \%-9 \%$; quartz: $5 \%-22 \%$ ) than in the other periods (feldspars: $3 \%-6 \%$; mafic: $0 \%-4 \%$; quartz: $3 \%-$ 
Table 1. Description of the SIGMA-D ice core dust samples.

\begin{tabular}{lrr|rrr}
\hline Period & \multicolumn{2}{c|}{ Ice } & \multicolumn{3}{c}{ Dust (size) } \\
\cline { 2 - 6 } & $\begin{array}{r}\text { Top } \\
(\mathrm{m})\end{array}$ & $\begin{array}{r}\text { Bottom } \\
(\mathrm{m})\end{array}$ & $\begin{array}{c}\text { Average } \\
(\mu \mathrm{m})\end{array}$ & $\begin{array}{r}\text { Maximum } \\
(\mu \mathrm{m})\end{array}$ & $\begin{array}{r}\text { Log-normal } \\
\text { mode }(\mu \mathrm{m})\end{array}$ \\
\hline $1915-1919$ & 37.00 & 38.60 & 1.97 & 12.80 & 0.73 \\
$1920-1924$ & 35.49 & 37.00 & 2.51 & 16.28 & 1.15 \\
$1925-1929$ & 33.80 & 35.49 & 2.22 & 26.51 & 0.46 \\
$1930-1934$ & 31.85 & 33.80 & 1.57 & 12.10 & 0.58 \\
$1935-1939$ & 30.22 & 31.85 & 2.27 & 20.09 & 0.59 \\
$1940-1944$ & 28.57 & 30.22 & 1.76 & 15.01 & 0.59 \\
$1945-1949$ & 26.87 & 28.57 & 2.53 & 21.85 & 0.97 \\
$1950-1954$ & 25.02 & 26.87 & 1.49 & 12.85 & 0.55 \\
$1955-1959$ & 23.67 & 25.02 & 2.01 & 14.09 & 0.75 \\
$1960-1964$ & 21.89 & 23.67 & 1.25 & 6.67 & 0.60 \\
$1965-1969$ & 19.95 & 21.89 & 1.27 & 9.65 & 0.53 \\
$1970-1974$ & 17.85 & 19.95 & 1.03 & 4.94 & 0.35 \\
$1975-1979$ & 16.30 & 17.85 & 1.02 & 5.53 & 0.43 \\
$1980-1984$ & 14.61 & 16.30 & 1.91 & 11.88 & 0.58 \\
$1985-1989$ & 12.50 & 14.61 & 1.22 & 5.54 & 0.47 \\
$1990-1994$ & 10.03 & 12.50 & 2.20 & 15.91 & 0.68 \\
$1995-1999$ & 7.56 & 10.03 & 2.08 & 14.86 & 0.77 \\
$2000-2004$ & 4.62 & 7.56 & 1.45 & 8.72 & 0.65 \\
$2005-2009$ & 2.31 & 4.62 & 1.88 & 11.29 & 0.60 \\
$2010-2013$ & 0.00 & 2.31 & 2.03 & 25.95 & 0.51 \\
\hline & & & & &
\end{tabular}
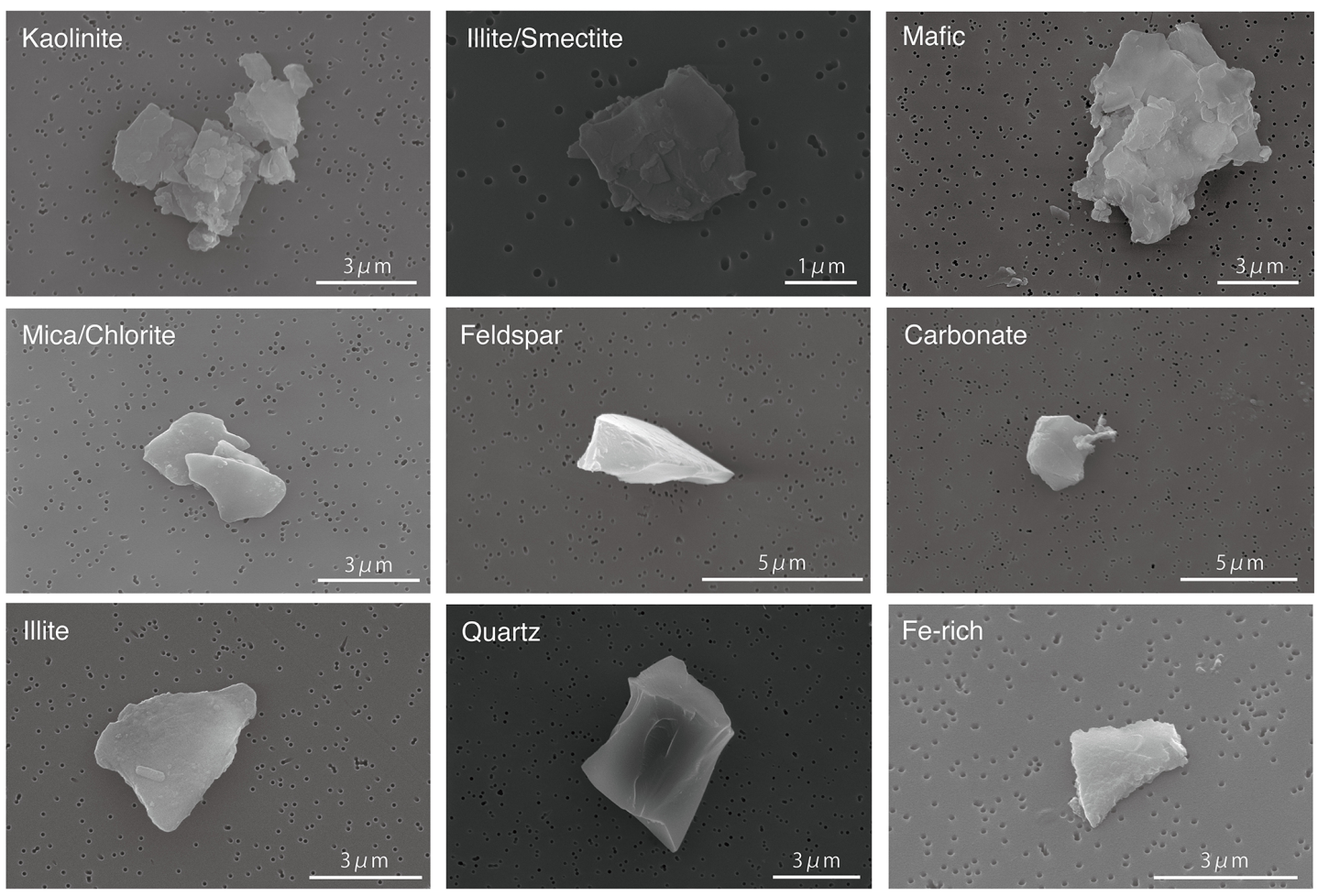

Figure 3. SEM images of each mineral group in the SIGMA-D ice core. 


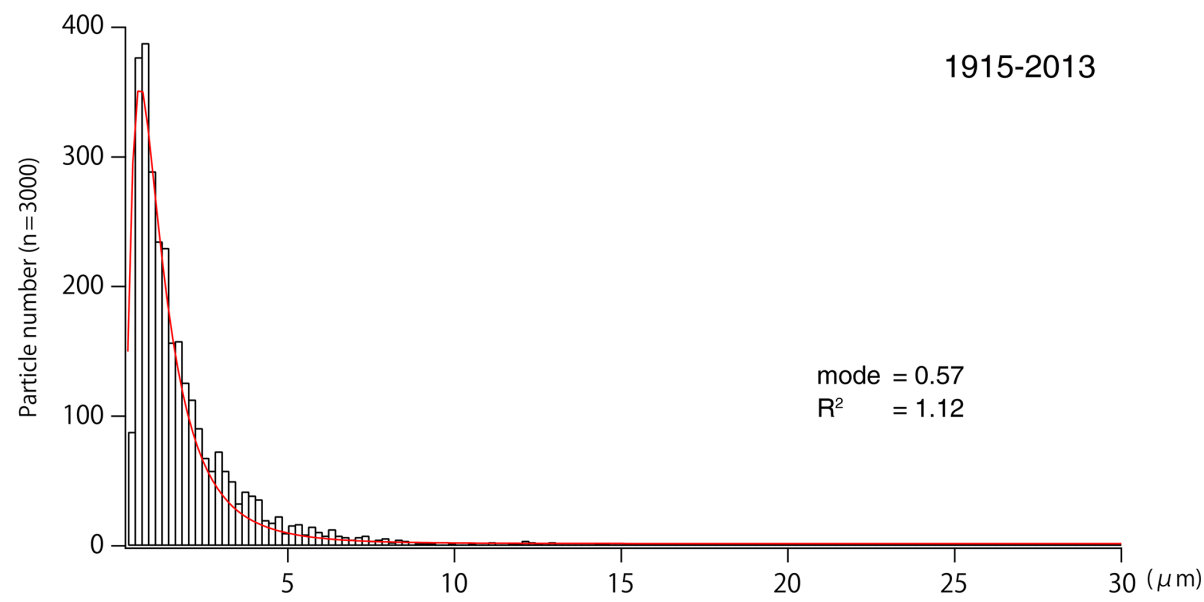

Figure 4. Particle size distribution and log-normal fitting results (mode: mode diameter and $R^{2}$ : half peak width) of minerals in the ice core samples from 1915 to 2013.

(a)

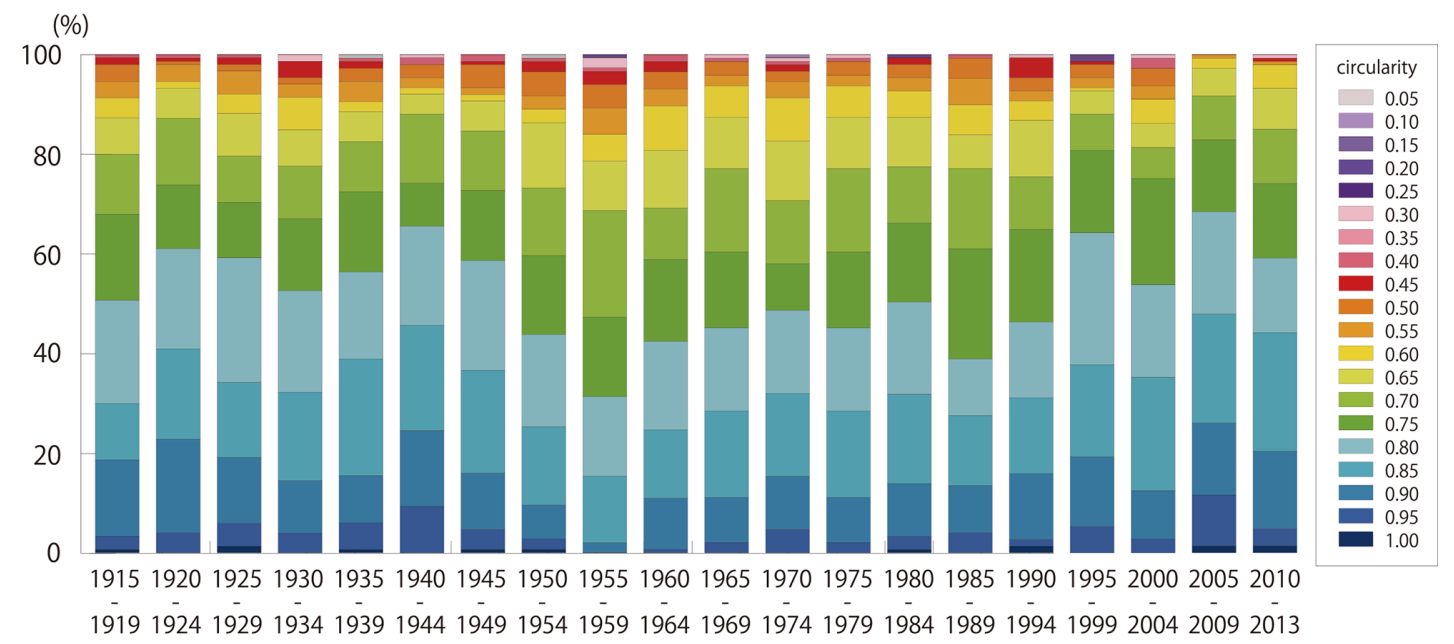

(b)

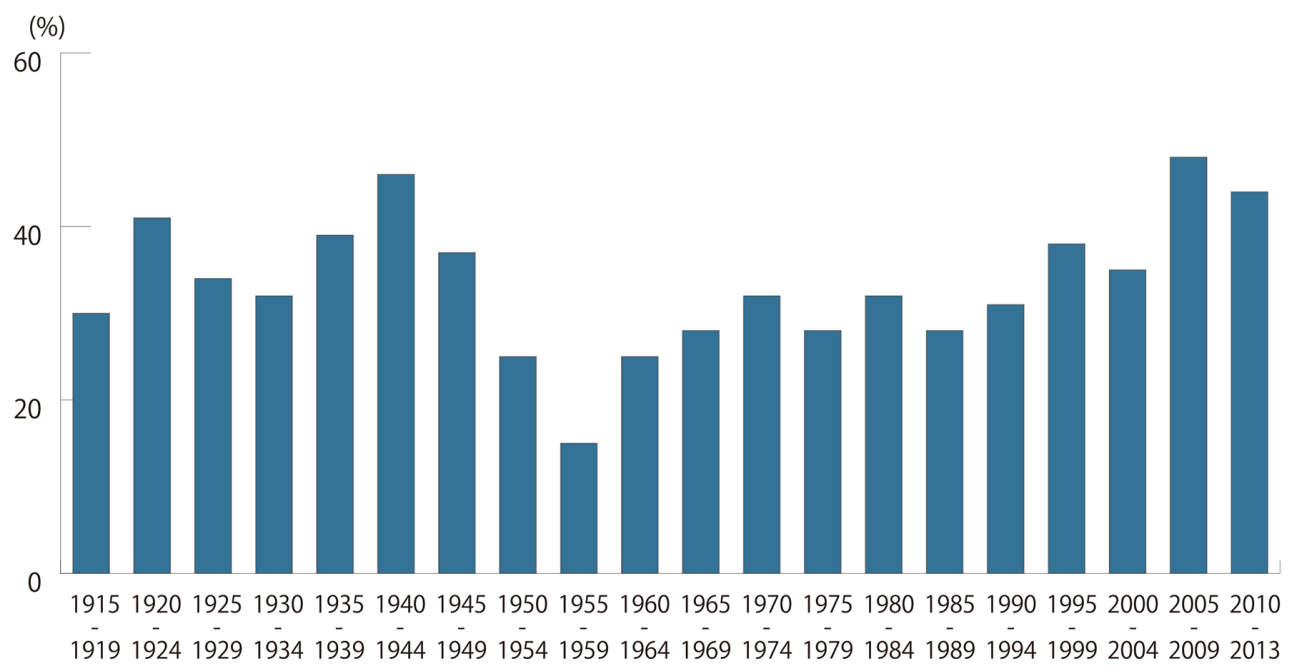

Figure 5. (a) Circularity distribution of mineral particles from different period. (b) Variation in proportion of circularity values of $>0.8$. 


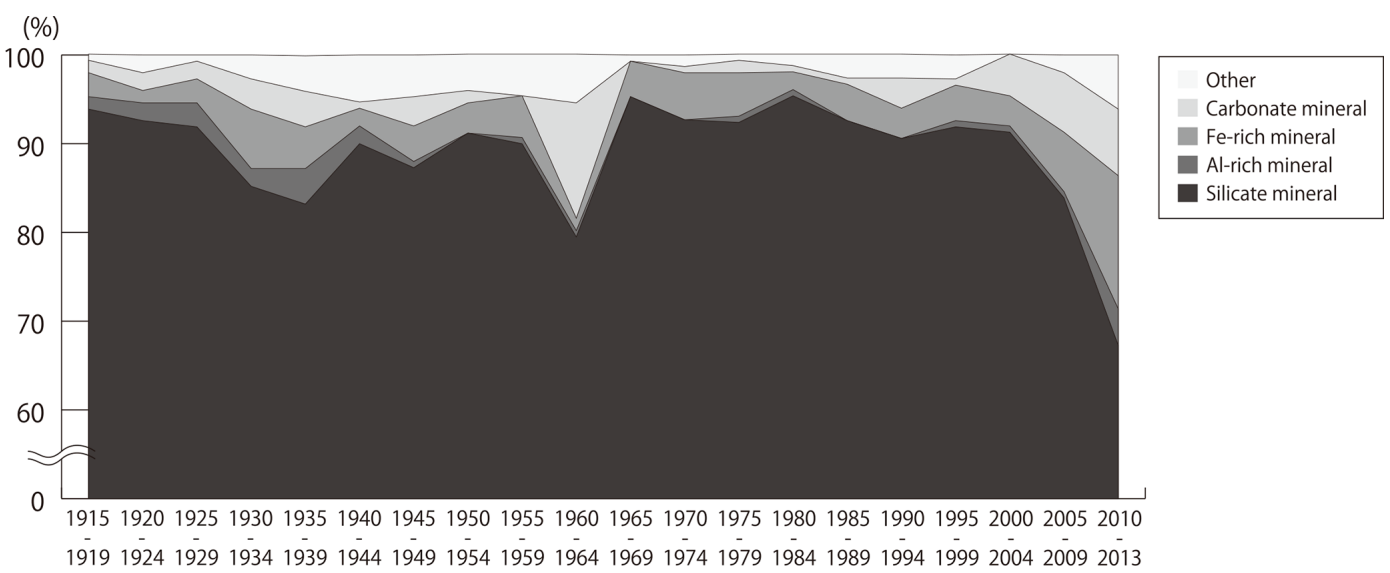

Figure 6. Variations in the insoluble mineral records in the ice core in 5-year resolution.

$6 \%$ ). Second, the compositions varied on shorter timescales, in inter-decadal cycles. Variations in the compositions of feldspars, mica, chlorite, and mica-chlorite mix were similar, but opposite to those of kaolinite and pyrophyllite.

Non-silicate minerals were also found in the ice core samples and were composed mainly of $\mathrm{Ca}$ - and $\mathrm{Fe}$-dominant minerals, identified as carbonates (calcite) and Fe-oxides (pyrite, magnetite, or hematite), respectively (Fig. 6). The relative abundance of both minerals, ranging from $0 \%$ to $15 \%$, has increased in the last 10 years. The carbonate minerals showed the highest abundance in the 1960-1964 sample.

\subsection{Source regions of SIGMA-D ice core dust}

To identify the source regions of the ice core dust, we applied the HYSPLIT back-trajectory model and calculated the probability distributions of an air mass arriving at the SIGMA-D site from 1958 to 2014 (Figs. $2 \mathrm{~b}$ and 8). The results show that the air mass at elevations above ground level from 0 to $1500 \mathrm{~m}$ came mainly from the western coast of Greenland, including the Baffin Bay, whereas a smaller part came from northern Canada (Figs. 2b and 8a). Excluding the ice sheet and ocean areas that could not be possible sources of mineral dust, the air mass is considered to have come mainly from the Greenland coast (50\%-60\%) and Canada $(\sim 40 \%)$, with a small contribution from northern Eurasia ( $\sim 3 \%$, Fig. 8 b). Contributions from these three possible source regions show little seasonal and inter-annual variabilities (Fig. $8 \mathrm{~b}$ and c). The air mass contribution from the Greenland coast was larger in dry deposition than wet deposition during summer, which may have caused an increase in dust sourced from local ice-free areas. However, there was no significant difference in the overall trend between the two deposition processes.

\section{Discussion}

\subsection{Variation in silicate mineral composition}

The SEM-EDS analysis revealed that the SIGMA-D ice core dust samples collected from 1915 to 2013 contained mainly silicate minerals, which is the most abundant family of crustal minerals (Deer et al., 1993). Silicate mineral composition showed variations on a multi- and inter-decadal scale, indicating that the ice core minerals originated from different geological sources in different periods during the past 100 years.

Variation trends in the silicate mineral composition of the SIGMA-D ice core samples substantially differed among mineral types (Fig. 9), indicating that the minerals in the ice core were derived from multiple geological sources. The dominance of Type A minerals in the samples from 1950 to 2004 indicated that the minerals might be derived mainly from low- or middle-latitude areas in the periods. In contrast, the abundance of Type B, C, D, and E minerals in the samples from 1915 to 1949 and from 2005 to 2013 indicated that the minerals were likely derived from arid deserts and/or highlatitude areas, including Greenland.

The morphological characteristics of the ice core dust also support the changes in the sources of silicate minerals. The size distribution of the minerals showed lower mean, maximum, and modal diameters from 1950 to 1989 compared with the other periods, when the samples consisted mainly of Type A minerals (Table 1, Fig. A2). The circularity also showed a similar trend, containing smaller amounts of particles with circularity values $>0.80$ from 1950 to 1989 (Fig. 5). The particle size depended on the mineralogy of the ice core dust. The coarser fraction $(>2 \mu \mathrm{m})$ of the ice core dust samples contained little clay, especially for Type A minerals (Fig. 10), but contained an abundance of Type C, D, and $\mathrm{E}$ minerals. This particle size dependence is consistent with other analyses of Greenland ice core dust (Biscaye, 1965; Svensson et al., 2000). Thus, the ice core dust was likely 
(a)

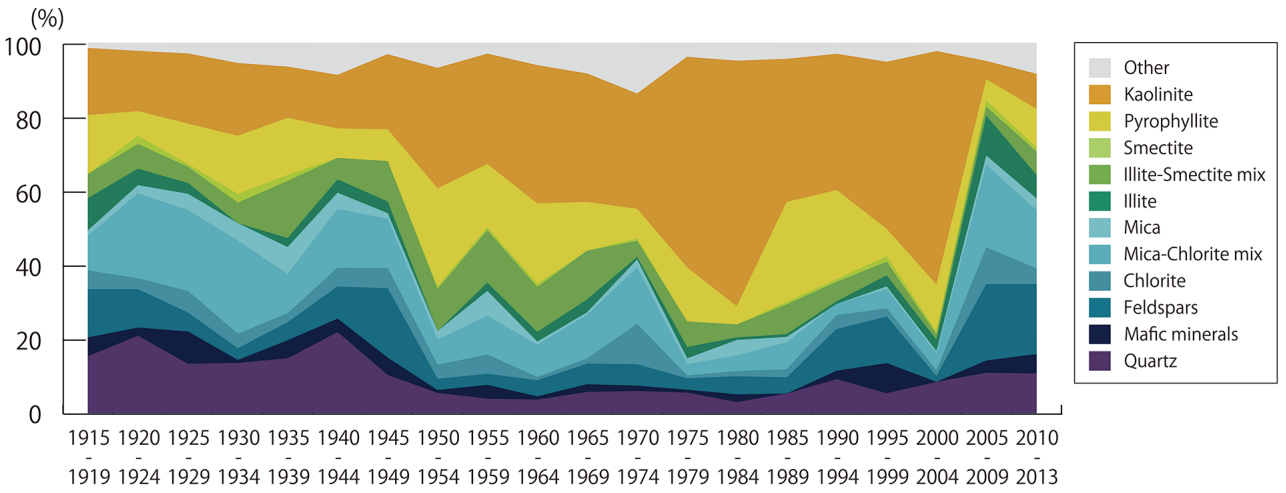

(b)
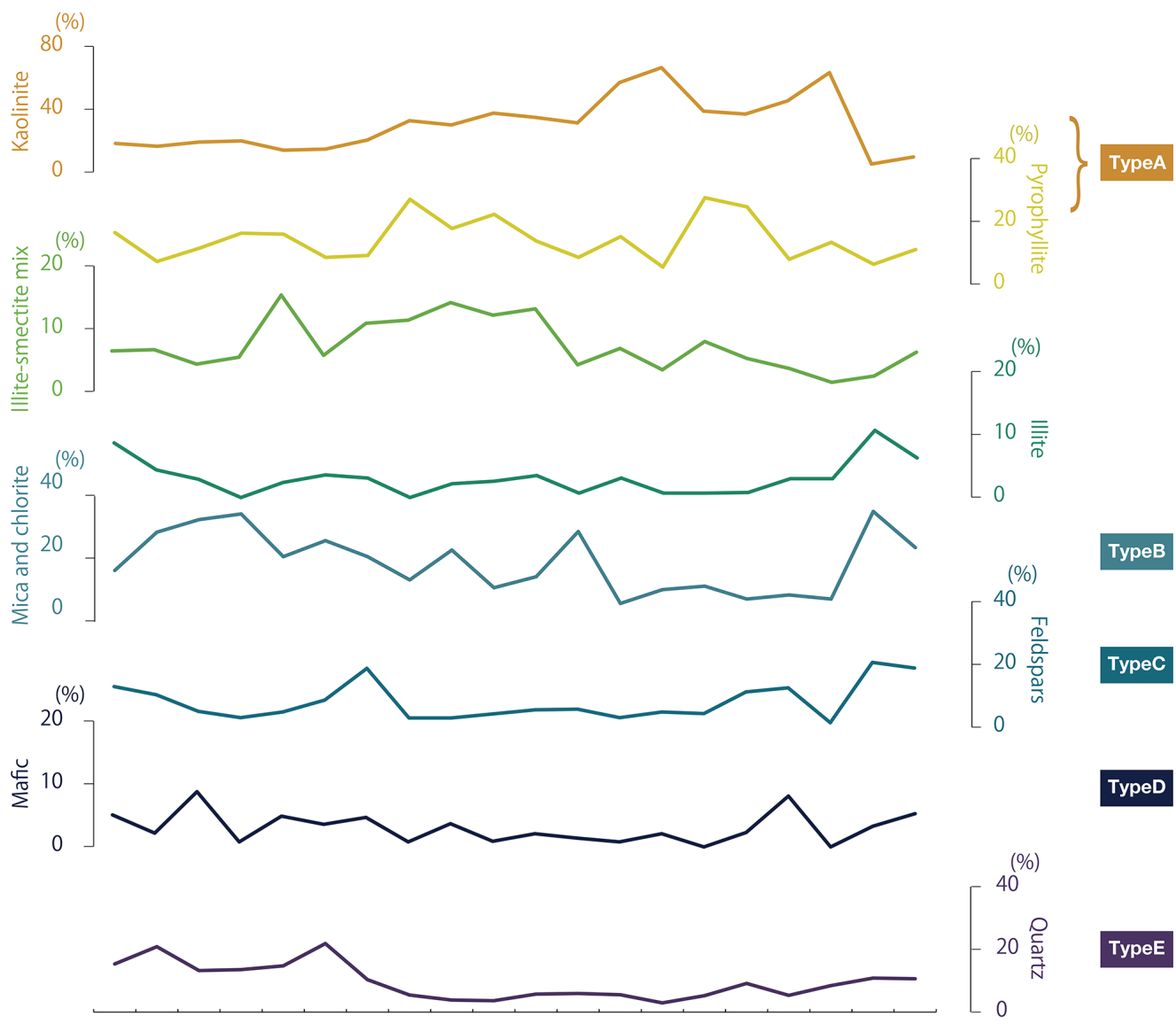

19151920192519301935194019451950195519601965197019751980198519901995200020052010

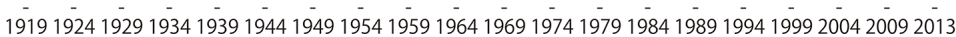

Figure 7. Variations in the silicate mineral records in the ice core in 5-year resolution. (a) Mineral composition and (b) proportion of each mineral. Mica and chlorite composed of mica, mica-chlorite mix, chlorite, and feldspars composed of Na/Ca-feldspar and K-feldspar.

derived from different geological sources in the late 1900s compared with the other periods.

\subsection{Possible causes of mineralogical variation}

One of the possible causes of the temporal variations in the silicate mineral composition is a surface temperature change in Greenland. Reconstructions of temperature variability in
Greenland have revealed there were two intense warming periods (1920s-1940s and since the 1990s) and a cooling period (1950s-1980s) in the past 100 years (e.g. Box et al., 2009; Kobashi et al., 2011; Cappelen, 2019). These trends were strong in the western coastal region and were similar to those of the silicate mineral compositions. The proportion of Type A minerals was low in the samples from 1915 to 1949 , increased from 1950 to 2004, and decreased again after 2005. 


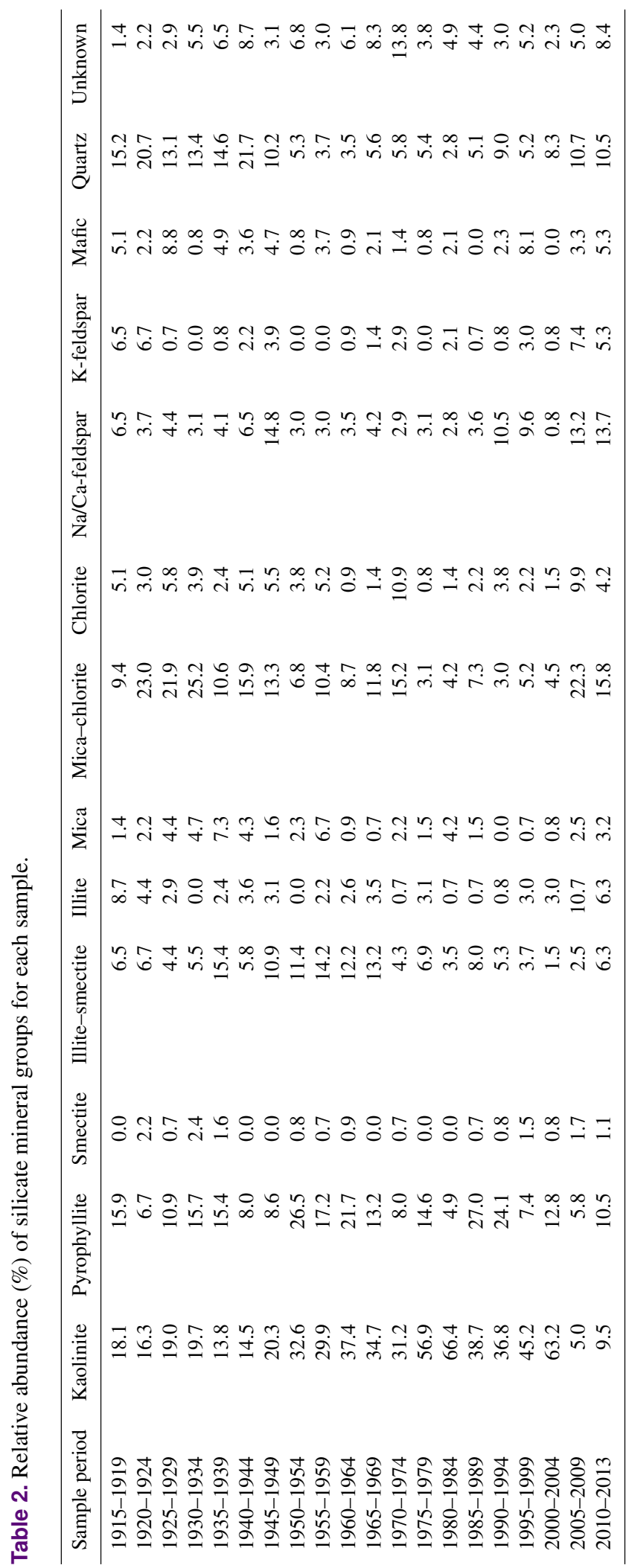

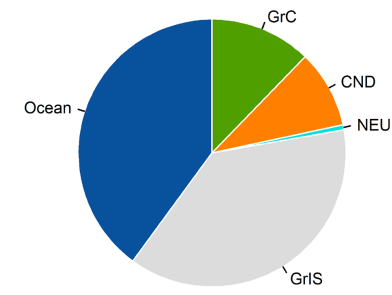

(a)
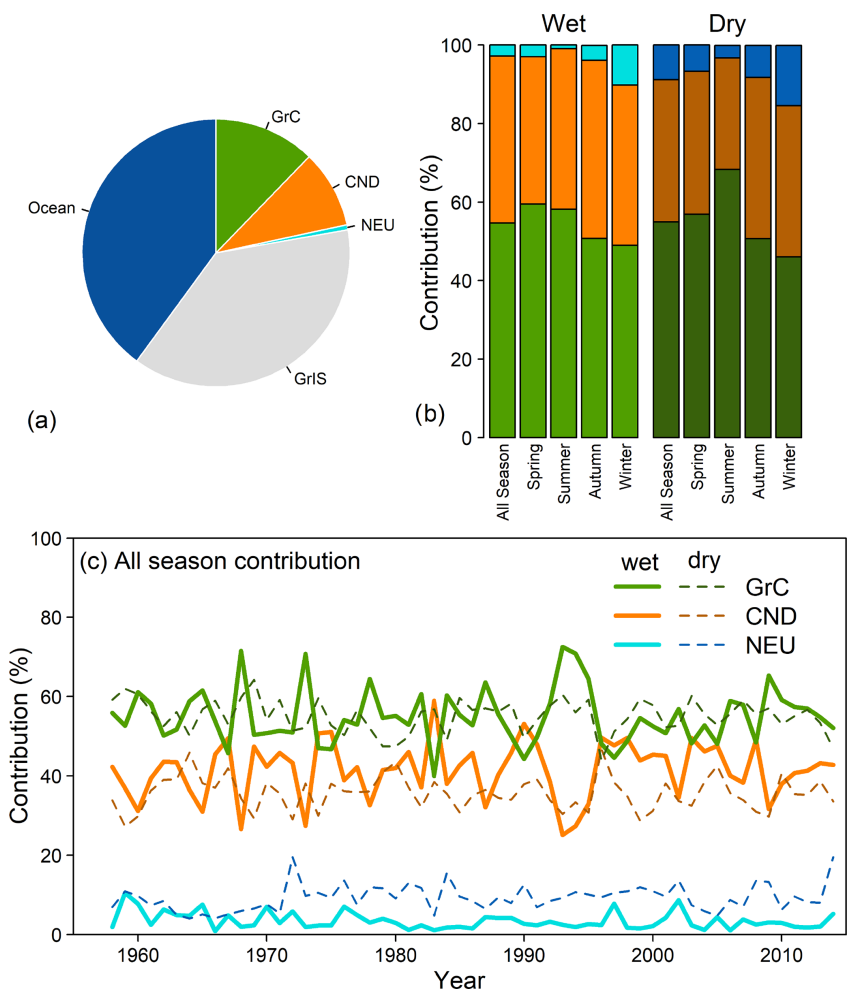

Figure 8. (a) Contribution of an air mass from possible source areas from 1958 to 2013, for which precipitation at the SIGMA-D site is taken into account. (b) Seasonal and (c) annual variations in the regional contribution of air mass to the SIGMA-D site through wet and dry depositions excluding the ice sheet and ocean areas. GrC, GrIS, CND, and NEU denote the ice-free Greenland coastal region (Fig. 1), Greenland Ice Sheet, Canada, and northern Eurasia, respectively (Fig. 2a).

In contrast, the proportion of Type $\mathrm{B}, \mathrm{C}, \mathrm{D}$, and $\mathrm{E}$ minerals showed the opposite trend. Therefore, Type A minerals were abundant in the colder periods, whereas Type B, C, D, and E minerals were abundant in the warmer periods (Fig. 9). These results suggest that the multi-decadal variation in SIGMA$\mathrm{D}$ ice core silicates was likely affected by local temperature changes in Greenland.

The North Atlantic Oscillation (NAO) is also thought to be a possible cause of compositional variations in the silicate minerals. The NAO is known to show inter-decadal variations and is strongly related to the incidence and intensity of blocking high pressure over Greenland (Woollings et al., 2010; Hanna et al., 2014). Thus, the NAO can change the atmospheric circulation patterns and transportation processes associated with the ice core dust, which could be related to inter-decadal variations in the silicates. However, there is no clear correlation between the NAO and silicate mineral records. One of the reasons for this may be the low sampling resolution, which makes it difficult to determine a correlation with the NAO index. 


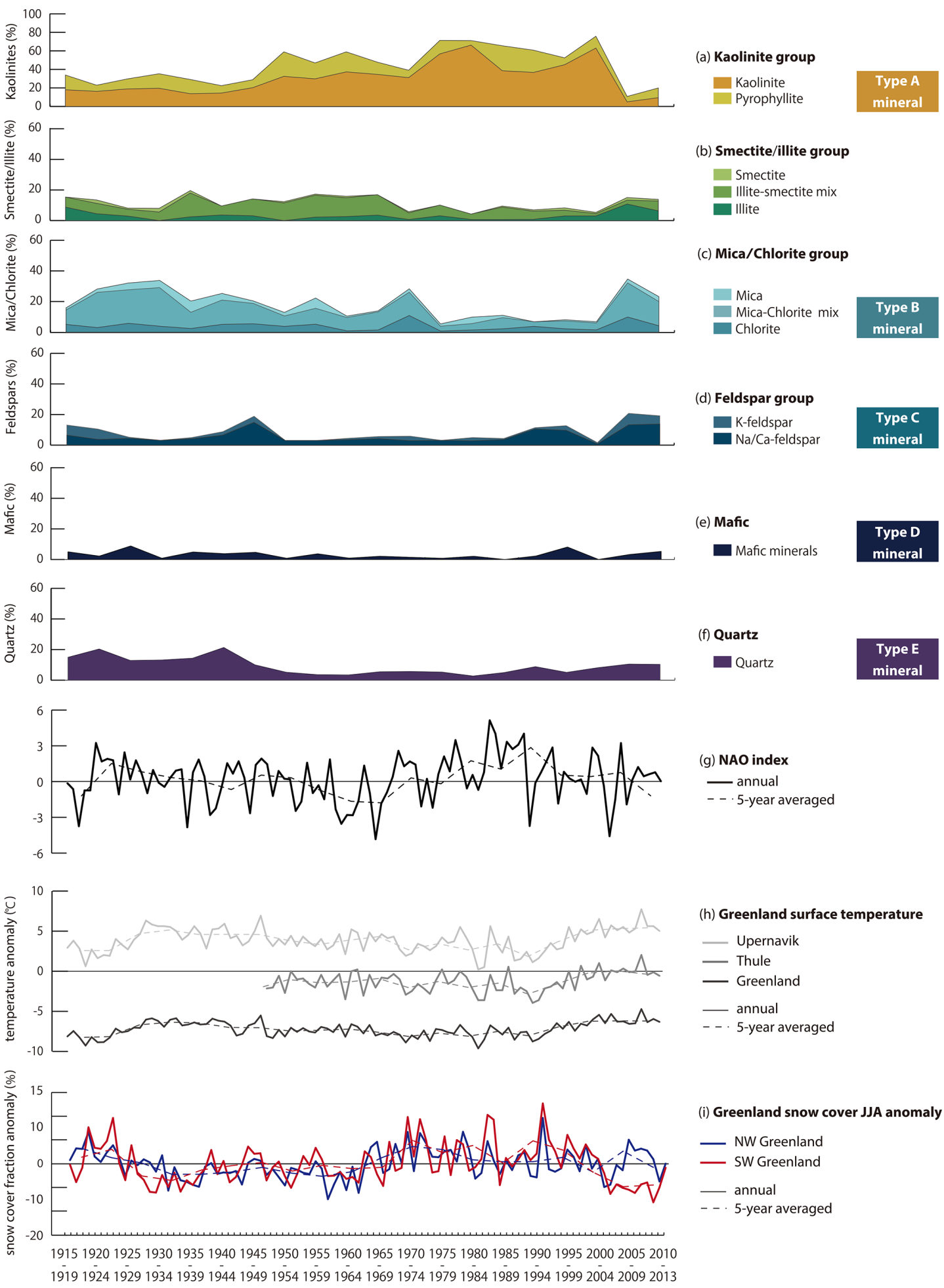

Figure 9. Comparison of historical changes in proportion of silicate minerals from the SIGMA-D ice core (a: kaolinite group, b: smectite group, c: mica-chlorite group, d: feldspar group, e: mafic mineral, f: quartz) with those in (g) the North Atlantic Oscillation index (NAO; Hurrell and National Center for Atmospheric Research Staff, 2020) and (h) surface temperature anomalies and (i) snow cover fraction anomalies in Greenland. Surface temperature anomalies deviate from the 1948-2013 average in Thule. The temperature record of Greenland is from Berkeley Earth, and Thule (Pituffik) and Upernavik in western Greenland located $100 \mathrm{~km}$ south and $650 \mathrm{~km}$ southeast of Qaanaaq are from Cappelen (2019). Snow cover fraction anomalies deviate from the 1915-2013 average in NW and SW Greenland. 


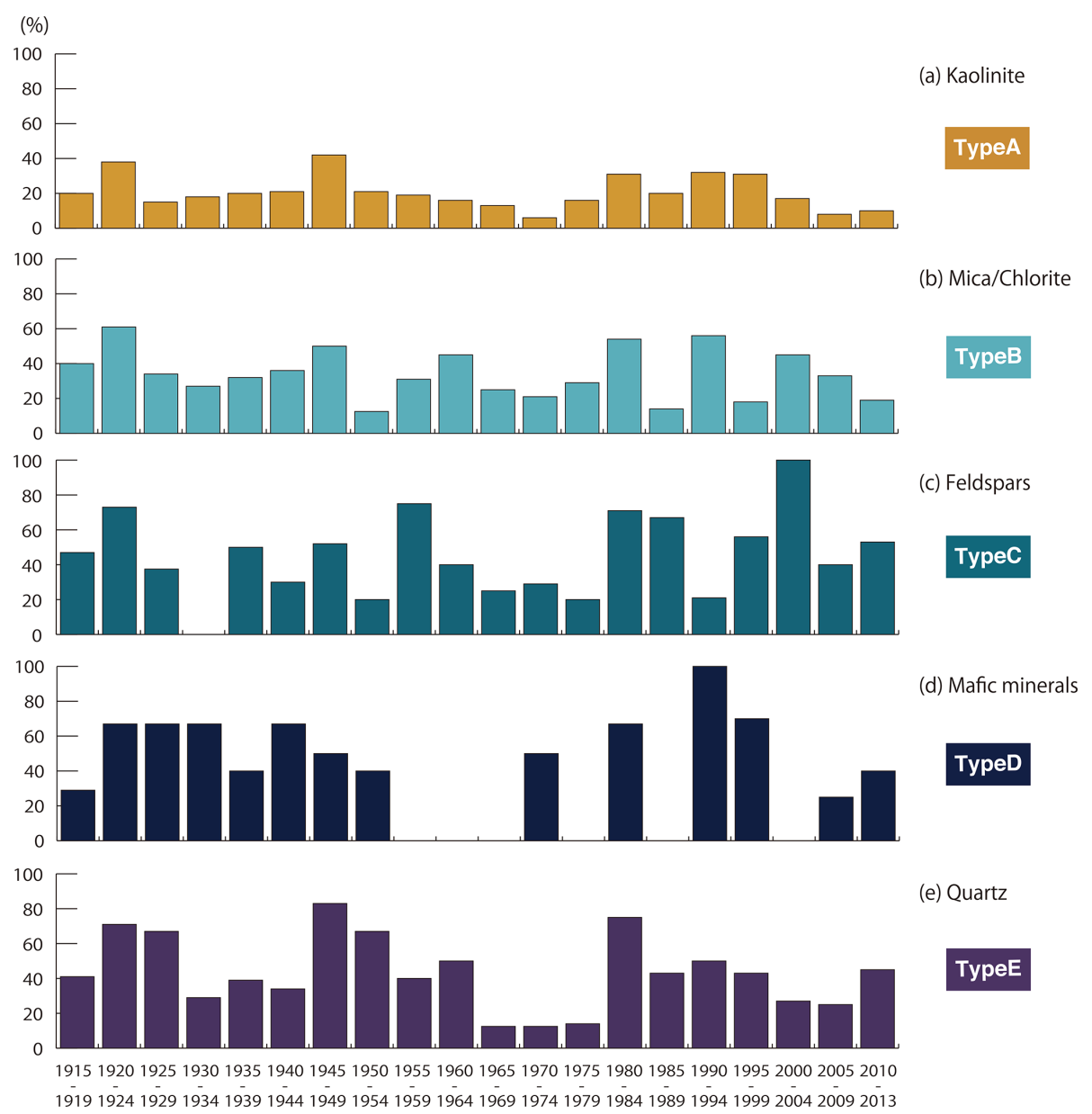

Figure 10. Historical changes in proportion of large particles (diameter $>2 \mu \mathrm{m})$ in (a) kaolinite, (b) mica-chlorite, (c) feldspars, $(\mathbf{d})$ mafic minerals, and (e) quartz.

In addition to the NAO, sulfate aerosols originating from volcanic eruptions have also been identified as another important cause of the cooling in Greenland, especially along the western ice sheet margins during the 1900s (Box et al., 2009), such as the Mt. Agung eruption in 1963, the Mt. St. Helens eruption in 1980, and the Mt. Pinatubo eruption in 1991. However, the chemical compositions of ash from these volcanoes (Taylor and Lichte, 1980; Pallister et al., 1992; Devi et al., 2019) were different from the composition of the Type A minerals that were abundant in the cooling period. The SEM observations also did not identify ice core minerals exhibiting morphological characteristics of volcanic ash. These results indicate that the effect of volcanic materials on the variation in silicate mineralogy may be negligible in the SIGMA-D ice core.

\subsection{Possible sources for mineral dust in the SIGMA-D ice core}

The trajectory analysis revealed that the majority of the air mass came from the western coast of Greenland and that a smaller proportion came from northern Canada between 1958 and 2014. The contribution from these two possible source regions showed little inter-annual variabilities (Fig. 8b and c), indicating that the transportation processes of the ice core dust have not substantially changed on an annual basis over the last 5 decades. Thus, the variations in the geological origins of the ice core dust were unlikely due to changes in air mass transportation. An alternative cause of dust variability could be a change in the surface conditions of the source areas. Retreats of the ice sheet and local glaciers have accelerated since 2000 in Greenland, increasing the exposure of the ground surface in snow/ice-covered areas in the coastal region (e.g. van den Broeke et al., 2009; Bendixen et al., 2017). Furthermore, the modelled snow cover fraction anomaly during summer (June, July, and August) on the northwest and southwest coasts of Greenland is negatively consistent with the temperature anomalies (Fig. 9h and i). The snow cover fractions are lower during the two warming periods of 1920s-1950s and 2000-2013. Given that the snow cover fraction should directly relate to the snow cover duration, this result suggests that the snow cover duration on 
the west coast of Greenland was shortened in the warming periods and thus might also have contributed to the increase in local dust emissions. Bullard and Mockford (2018) analysed records of dust events in the western Greenland coastal region and revealed that the annual severity of dust emissions was higher from 2000 to 2010 than during the preceding decades. This was likely due to increasing meltwater runoff delivering sediments from the ice sheet to outwash plains with the increase in atmospheric temperature. High dust emissions on the western coast of Greenland occurred in spring and summer, when the snow cover is rapidly decreasing (Bullard and Mockford, 2018). Our trajectory analysis also indicated that the air mass contribution from the Greenland coast was slightly larger in spring and summer than in autumn and winter (Fig. 8b). Therefore, the snow/ice cover duration in the Greenland coastal region was shortened by the recent warming during the melt season, causing an increase in the local supply of dust to the SIGMA-D site. Although no satellite observations are available for the first warming period (1920s-1940s), aerial photos, maps, and paintings indicated ice retreat in Greenland (Box and Herrington, 2007). Thus, the abundant Type B, C, D, and E minerals found in the two warming periods were likely due to an increase in dust sourced from local ice-free areas.

The ice core dust morphology and composition also indicated a contribution from local sediment in the warming periods. Simonsen et al. (2019) used particles with diameters of $<2$ and $>8 \mu \mathrm{m}$ as indicators of distant and local dust sources, respectively, for the Renland Ice Cap Project ice core in eastern Greenland. The size distribution of SIGMA$\mathrm{D}$ ice core dust showed that the samples from the cold period (1950-1999) contained fewer particles with diameters of $>8 \mu \mathrm{m}$ ( $0-4$ particles) than those from the warm periods (1915-1949 and 2000-2013; 1-9 particles). Furthermore, the higher proportions of Type $\mathrm{C}$ and $\mathrm{E}$ minerals in the SIGMAD ice core samples in 1915-1949 and 2000-2013 correspond to higher concentrations of the two minerals in the surface dust and soil on and around the Qaanaaq Glacier (Nagatsuka et al., 2014). Since the Abakus laser particle sensor connected to the CFA system detected particles with diameters of 1.5 and $15 \mu \mathrm{m}$ and CFA analysis has not been performed since 2003 (above a depth of $6.35 \mathrm{~m}$ ) due to poor core quality, we cannot compare the size distribution data with that measured by the SEM. However, the Abakus dust profiles (Fig. A3) showed higher concentration for the particles with diameters of $>1.5,>5$, and $>8 \mu \mathrm{m}$ in the warm period (1915 to the 1950s) compared with the cold period (1955-1999, except for a large peak in 1978), which supports an increase in local dust contribution from 1915 to the 1950s as shown by the SEM-EDS results.

Previous studies indicated dust transport from distant deserts, such as those in Asia and Africa, which are another possible source for three of the mineral types (B, C, and E) found at high-elevation sites on the Greenland Ice Sheet during the past century (Bory et al., 2003a; Drab et al., 2002).
However, our trajectory analysis showed little contribution from these regions in the $7 \mathrm{~d}$ back trajectory. A similar analysis of an ice core on the southeastern coast of Greenland suggested that air mass contribution from Asian and arid regions was negligible, even for the $25 \mathrm{~d}$ back trajectory (lizuka et al., 2018). Schüpbach et al. (2018) also reported little contribution of air mass from Asian arid regions and addressed a limitation of the back-trajectory analysis, namely that it could not capture dust transport from Asia to Greenland, which might be through the upper troposphere. Bory et al. (2003b) suggested that sources providing dust to an ice core site are dependent on distance from the ice sheet margin and/or the altitude and that long-range transport from Asian deserts likely accounts for most of the dust deposited at interior sites (NGRIP, GRIP, Site-A, and Dye-3), whereas local sources represent an additional and primary contributor at coastal sites in Greenland (Hans Tausen and Renland). Our $7 \mathrm{~d}$ back-trajectory analysis shows the significantly low contribution of air masses from Asian and arid regions (less than $0.1 \%$ ), whereas the air mass contribution from the Greenland coast is high (7\%-14\%), especially for Renland and Hans Tausen, followed by the Sigma-D site (Fig. 11a and d). The mineralogical composition of SIGMA-D also showed a substantially lower proportion of Type B (chlorite) and Type E minerals and a higher proportion of Type A minerals (1\%$11 \%, 3 \%-22 \%, 5 \%-66 \%)$ compared with other Greenland ice core dust originating from Asian deserts (e.g. GRIP: $12 \%-27 \%, 28 \%-48 \%, 4 \%-16 \%$; Svensson et al., 2000). Thus, very little of the mineral dust in the ice core from SIGMA-D, which is located in a coastal area, may have come from distant deserts, whereas a large proportion likely came from the local areas in the warming periods.

Possible sources of ice core dust in the colder period (1950-2004) are likely to be found in low to mid-latitudes because the Type A mineral that is typical of humid tropical climatic zones such as modern-day Africa, South America, and Southeast Asia was abundant in that period. Although back-trajectory analysis cannot estimate contributions from distant sources as described above, it is unlikely that large amounts of ice core dust were transported from such tropical regions. However, our back-trajectory analysis suggests that northern Canada might also be a possible source of Type A minerals, and some studies support this argument (Fig. 11b). For example, Darby (1975) analysed the clay mineral composition of marine sediments from deep-sea cores in the Arctic Ocean and revealed that there was abundant kaolinite (Type A minerals) apparently derived from shale and soils of northern Alaska and northern Canada, which were relict deposits of warmer climates in the Tertiary. This abundant kaolinite was deposited in a non-marine environment (Allen and Johns, 1960). Clay mineralogy of North Sea basin sediment cores also revealed that increased kaolinite concentrations were associated with the Paleocene-Eocene Thermal Maximum (Kemp et al., 2016). The Type A minerals were likely transported from such ancient soils formed by chemi- 

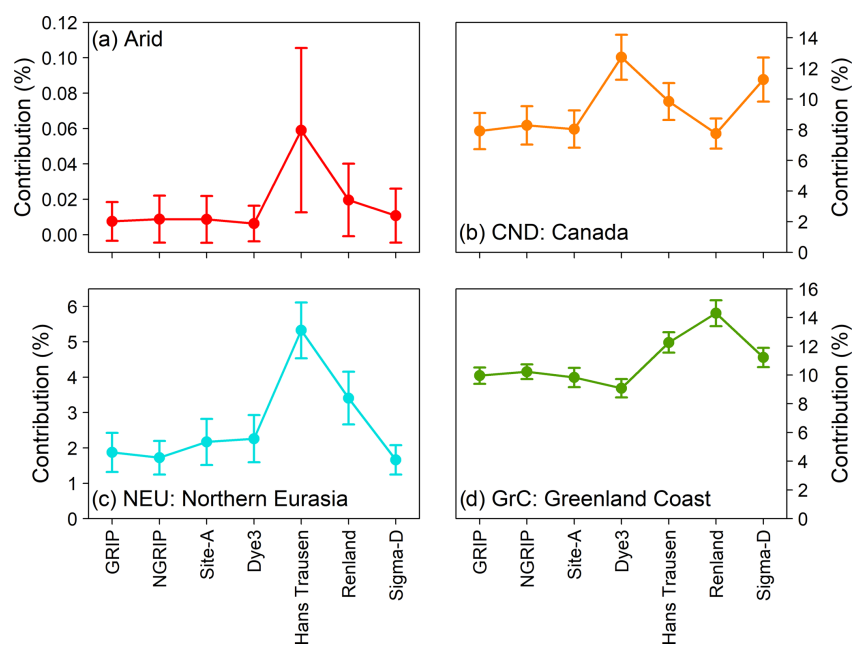

Figure 11. Air mass contribution for the $7 \mathrm{~d}$ back trajectory from (a) arid regions (China, Central Asia, and the Middle East), (b) North America (Canada and US), (c) Eurasia (EU and Russia), and (d) the Greenland coast at the seven ice core sites on Greenland. Error bars indicate the standard deviation of contributions from 1981 to 2010.

cal weathering in high-latitude areas in past warming events. Thus, we concluded that northern Canada is likely the best candidate for the SIGMA-D ice core dust source during the cold period.

The SEM-EDS results of the SIGMA-D ice core dust can demonstrate variations in the ice core dust sources over the past 100 years. The relatively higher proportion of Type A minerals (more than $30 \%$ ) in almost all the periods indicates that the ice core dust was constantly supplied from a distant source (mainly northern Canada) to the SIGMA-D site and that the source areas have not changed over the past 100 years. However, dust was additionally provided from local ice-free areas in the warm periods (1915-1949 and 20052013) because the snow/ice cover duration in the Greenland coastal region was shortened by the recent warming during the melt season.

\section{Conclusions}

Analysis of the SEM-EDS of individual dust morphology and mineralogy in the SIGMA-D ice core revealed that the ice core dust consisted mainly of silicate minerals, including quartz, feldspars, and mafic minerals, and clay minerals, including kaolinite, illite, smectite, mica, and chlorite. Most of the particles had a diameter of $<2 \mu \mathrm{m}$, implying that the ice core contained mainly long-range-transported windblown mineral dust. The silicate mineral composition varied substantially on multi-decadal and inter-decadal scales. The multi-decadal variation trend differed among mineral types formed in different source areas, which corresponded to surface temperature changes in Greenland; kaolinite, which is typical of humid tropic climatic zones, was abundant in the colder period (1950-2004), whereas mica, chlorite, feldspars, mafic minerals, and quartz, which are generally formed in arid, high-latitude, and/or local areas, were abundant in the warmer periods (1915-1949 and 2005-2013). This indicates that the ice core minerals originated from different geological sources in different periods during the past 100 years. The multi-decadal variation in the relative abundance of the minerals was likely affected by local temperature changes in Greenland. The trajectory analysis showed that the air mass arriving at the SIGMA-D site came mainly from the western coast of Greenland and that a smaller proportion came from northern Canada during 1958-2013. The contributions from the two showed little inter-annual variability, indicating that an alternative cause of variability in the geological origins of the ice core dust was likely to be a change in the surface conditions of source areas rather than in air mass transportation. The abundant mineral types in the two warmer periods might be explained as an increase in dust sourced from local ice-free areas resulting from shortened snow/ice cover duration in the Greenland coastal region caused by the recent warming during the melt season. Meanwhile, ancient deposits in northern Canada, which were formed in past warmer climates, seem to be the best candidate during the colder period (1950-2004). We concluded that ice core dust was constantly supplied from distant sources (mainly northern Canada) to the SIGMA-D site as well as local ice-free areas in the warm periods. Although further analyses are needed to identify the cause of interdecadal variations in ice core dust, our study is the first to demonstrate a high-temporal-resolution record of mineral composition in a Greenland ice core over the past 100 years. 


\section{Appendix A}

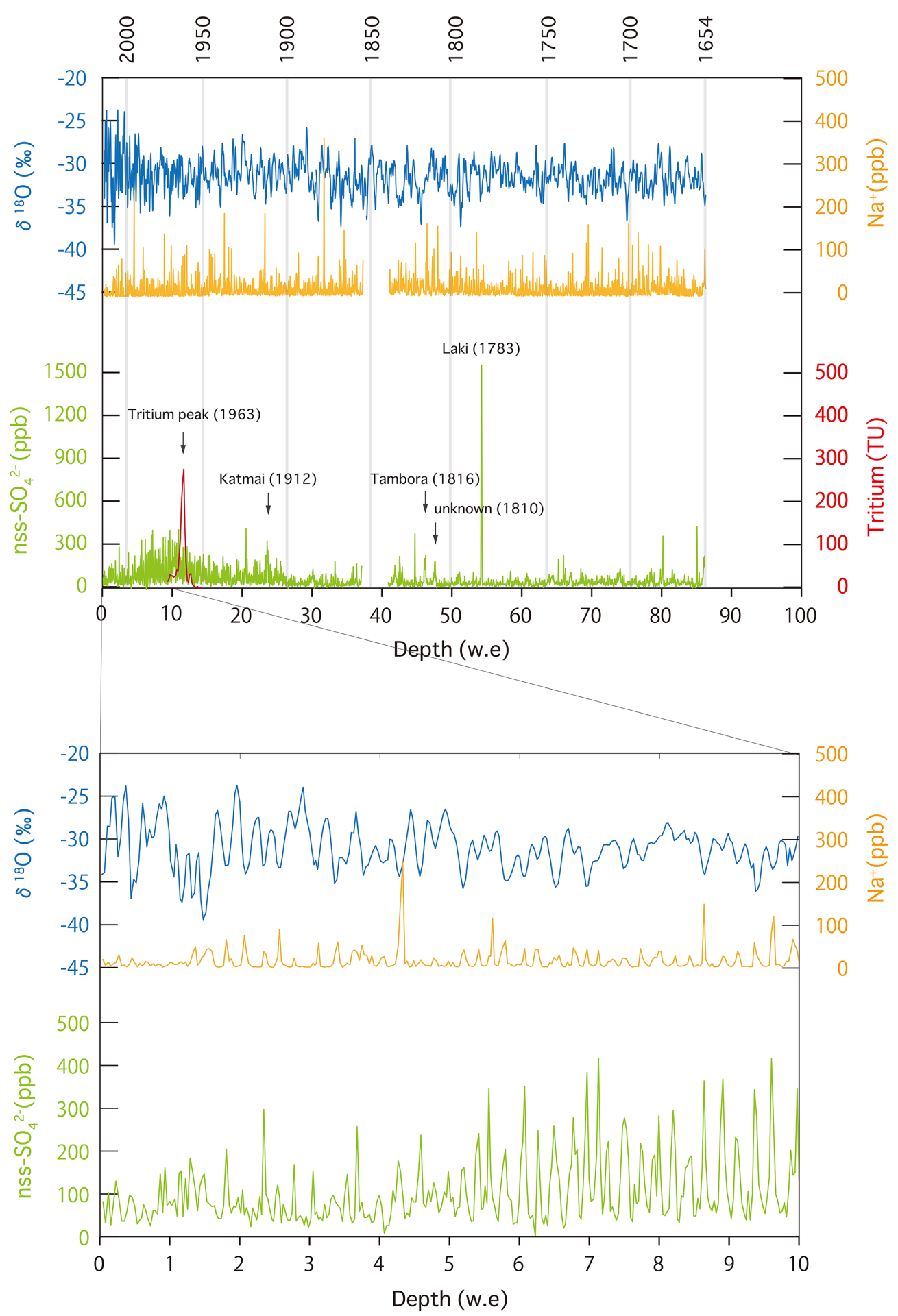

Figure A1. $\delta^{18} \mathrm{O} \mathrm{Na}^{+}, \mathrm{nssSO}_{4}^{2-}$, and tritium records in the upper $112.87 \mathrm{~m}(86.06 \mathrm{~m}$ w.e.) of the SIGMA-D ice core. Major volcanic signals we identified are shown in the nssSO $\mathrm{S}_{4}^{2-}$ record. The bottom plots show the enlarged record from 0 to $10 \mathrm{~m}$ w.e. 
(a)
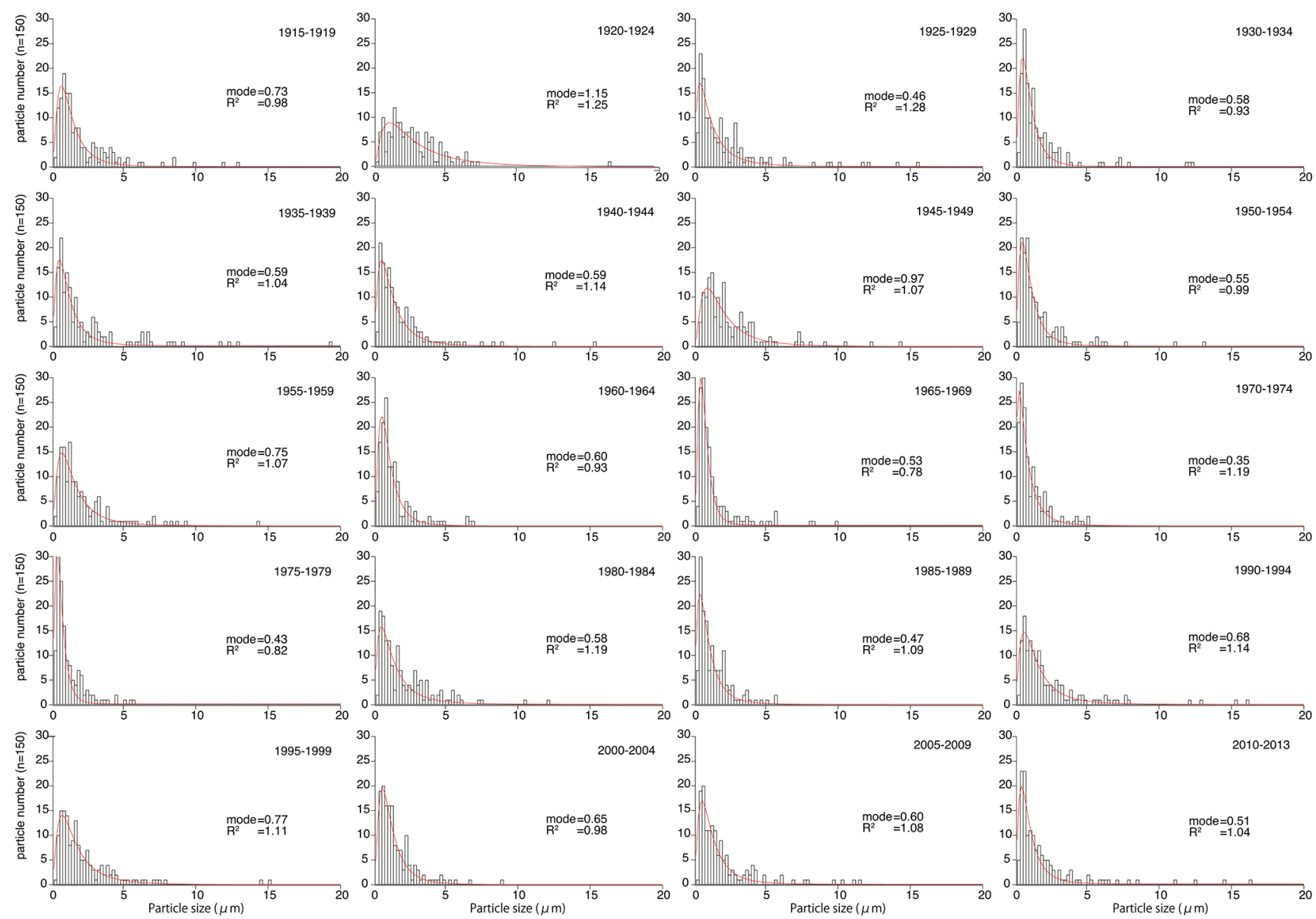

(b)
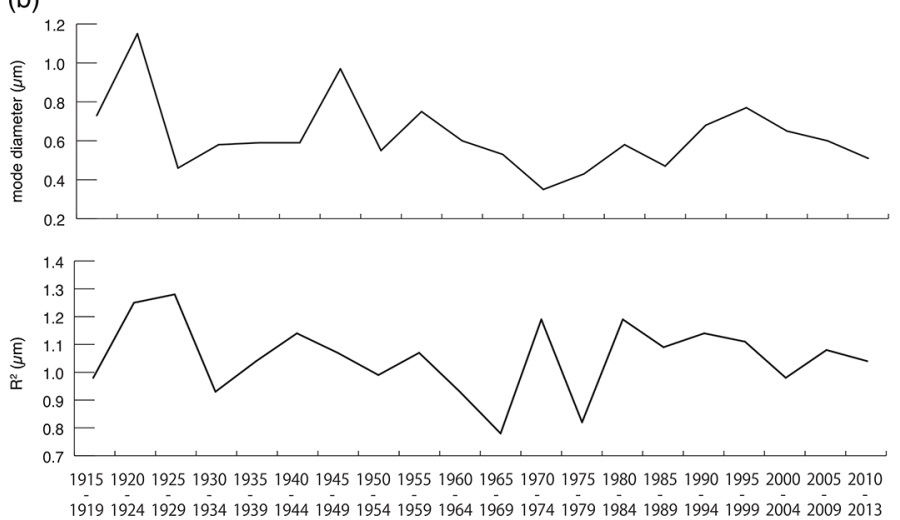

Figure A2. (a) Comparison of particle size distribution and log-normal fitting results (mode: mode diameter and $R^{2}$ : half peak width) of the ice core minerals among the samples. (b) Historical changes in the mode diameter and $R^{2}$. 
(a)

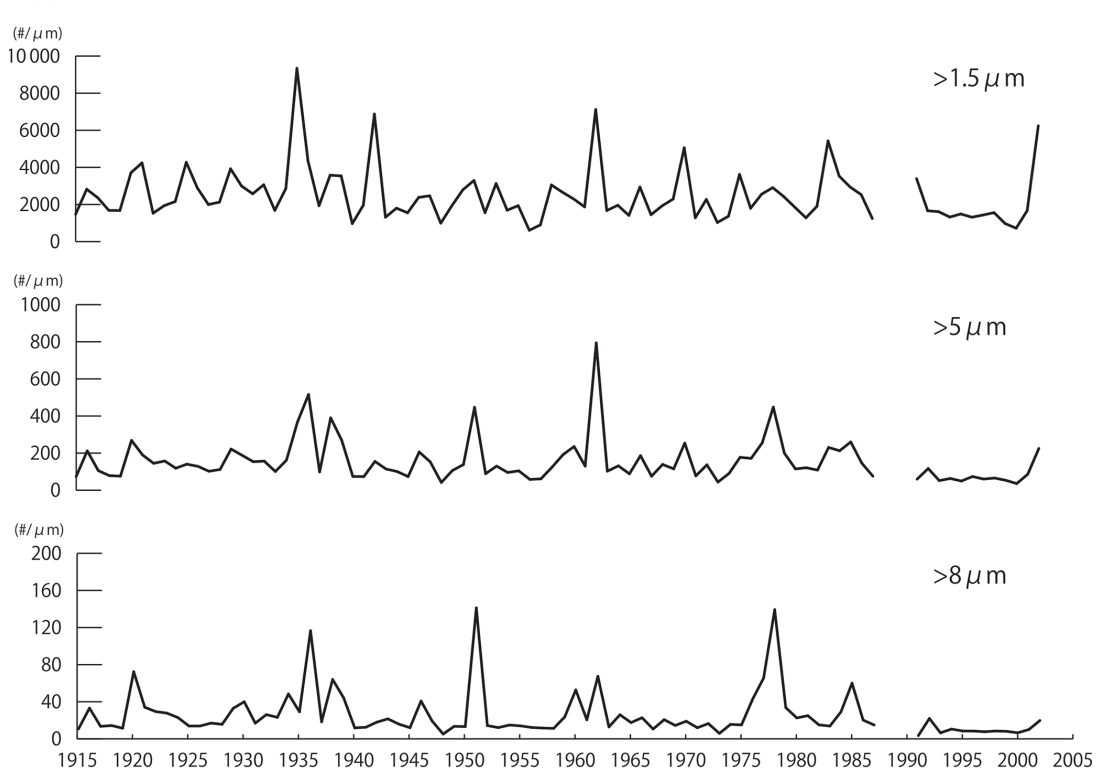

(b)

\begin{tabular}{|c|c|c|c|}
\hline & $>1.5 \mu \mathrm{m}$ & $>5 \mu \mathrm{m}$ & $>8 \mu \mathrm{m}$ \\
\hline $1915-1954$ & 2736.8 & 163.3 & 29.6 \\
\hline $1955-1999$ & 2235.7 & 149.0 & 24.1 \\
\hline
\end{tabular}

Figure A3. (a) Annual average number concentration of the SIGMA-D ice core dust particles with diameters of $>1.5,>5$, and $>8 \mu \mathrm{m}$ from 1915 to 2002 as measured by the Abakus laser particle sensor and (b) the averaged concentrations from 1915 to 1954 and from 1955 to 1999. 
Data availability. Datasets used in this study are available at the following DOIs.

MIROC6 model output prepared for CMIP6 LS3MIP experiments is available at

https://doi.org/10.22033/ESGF/CMIP6.5622 (land-hist: Onuma and Kim, 2020a),

https://doi.org/10.22033/ESGF/CMIP6.5627 (land-histcruNcep: Onuma and Kim, 2020b),

https://doi.org/10.22033/ESGF/CMIP6.5628

(land-hist-

princeton: Onuma and Kim, 2020c), and

https://doi.org/10.22033/ESGF/CMIP6.5629 (land-hist-wfdei: Onuma and Kim, 2020d).

$\delta^{18} \mathrm{O}$, ion concentrations, and mineral dust data are available at https://doi.org/10.17592/001.2021052501 (Nagatsuka et al., 2021).

Author contributions. NN designed the study and carried out the ice core dust analysis and wrote the manuscript with the help of KGA and KF. KF, SM, YO, YK, MM, and HM drilled the ice core. AT, SM, MK, and MH obtained ion concentration and water isotope data. NN, AT, KF, SM, and MK analysed the chronology of the ice core. KF conducted the back-trajectory analysis. YO conducted the CMIP6 model analysis. RD, MH, JO, YOT, KK, and KGA conducted the CFA analysis. KGA and YOT analysed the dust data. TA initiated the project. All authors discussed and commented on the paper.

Competing interests. The authors declare they have no conflicts of interest.

Acknowledgements. We would like to thank Tetsuhide Yamasaki for general fieldwork support. We also thank the two reviewers Anders Svensson and Laluraj C. M. and the editor Elizabeth Thomas for valuable suggestions, which substantially improved this paper.

Financial support. This research has been supported by the Japan Society for the Promotion of Science (JSPS) Fellowship (SIGMA project (grant nos. 23221004 and 16H01772) and 15H01731, 15K16120, 16J08380, 16H06291, 18H03363, 18H04140, 19K20443, 20H04980), the Integrated Research Program for Advancing Climate Models from the Ministry of Education, Culture, Sports, Science and Technology (MEXT, Japan (grant no. JPMXD0717935457)), the Arctic Challenge for Sustainability (ArCS (grant no. JPMXD130000000)), the Arctic Challenge for Sustainability II (ArCS II (grant no. JPMXD1420318865)), the Environment Research and Technology Development Fund of the Environmental Restoration and Conservation Agency of Japan (grant nos. JPMEERF20172003 and JPMEERF20202003), and the National Institute of Polar Research, Japan, through project research no. KP305.
Review statement. This paper was edited by Elizabeth Thomas and reviewed by Anders Svensson and Laluraj C. M.

\section{References}

Allen, V. T. and Johns, W. D.: Clays and clay minerals of New England and Eastern Canada, GSA Bulletin, 71, 75-86, https://doi.org/10.1130/00167606(1960)71[75:CACMON]2.0.CO;2, 1960.

Amino, T., Iizuka, Y., Matoba, S., Shimada, R., Oshima, N., Suzuki, T., Ando, T., Aoki, T., and Fujita, K.: Increasing dust emission from ice free terrain in southeastern Greenland since 2000, Polar Sci., 27, 100599, https://doi.org/10.1016/j.polar.2020.100599, 2021.

Bendixen, M., Iversen, L. L., Bjørk, A. A., Elberling, B., Westergaard-Nielsen, A., Overeem, I., Barnhart, K. R., Khan, S. A., Box, J. E., and Abermann, J.: Delta progradation in Greenland driven by increasing glacial mass loss, Nature, 550, 101104, https://doi.org/10.1038/nature23873, 2017.

Bergaya, F., Theng, B. K. G., and Legaly, G. (Eds.): Handbook of Clay Science. Development in Clay Science, Elsevier, Amsterdam, 2006.

Biscaye, P. E.: Mineralogy and sedimentation of recent deepsea clay in the Atlantic Ocean and adjacent seas and oceans, GSA Bulletin, 76, 803-832, https://doi.org/10.1130/00167606(1965)76[803:MASORD]2.0.CO;2, 1965.

Biscaye, P. E., Grousset, F. E., Revel, M., Van der Gaast, S., Zielinski, G. A., Vaars, A., and Kukla, G.: Asian provenance of glacial dust (stage 2) in the Greenland Ice Sheet Project 2 ice core, Summit, Greenland, J. Geophys. Res., 102, 26765-26781, https://doi.org/10.1029/97JC01249, 1997.

Bory, A. J.-M., Biscaye, P. E., and Grousset, F. E.: Two distinct seasonal Asian source regions for mineral dust deposited in Greenland (NorthGRIP), Geophys. Res. Lett., 30, 1167, https://doi.org/10.1029/2002GL016446, 2003a.

Bory, A. J.-M., Biscaye, P. E., Piotrowski, A. M., and Steffensen, J. P.: Regional variability of ice core dust composition and provenance in Greenland, Geochem. Geophy. Geosy., 4, 1107, https://doi.org/10.1029/2003GC000627, 2003b.

Box, J. E. and Herrington, A.: Was there a 1930's meltdown of Greenland glaciers?, American Geophysical Union Fall Meeting, San Francisco, USA, 10-14 December 2007, C11A-0077, 2007.

Box, J. E., Yang, L., Bromwich, D. H., and Bai, L.: Greenland Ice Sheet Surface Air Temperature Variability: 1840-2007, J. Climate, 22, 4029-4049, https://doi.org/10.1175/2009JCLI2816.1, 2009.

Bullard, J. E. and Austin, M. J.: Dust generation on a proglacial floodplain, West Greenland, Aeolian Res., 3, 43-54, https://doi.org/10.1016/j.aeolia.2011.01.002, 2011.

Bullard, J. E. and Mockford, T.: Seasonal and decadal variability of dust observations in the Kangerlussuaq area, west Greenland, Arct. Antarct. Alp. Res., 50, S100011, https://doi.org/10.1080/15230430.2017.1415854, 2018.

Capo, R. C., Stewart, B. W., and Chadwick, O. A.: Strontium isotopes as tracers of ecosystem processes: theory and methods, Geoderma, 82, 197-225, https://doi.org/10.1016/S00167061(97)00102-X, 1998. 
Cappelen, J. (Ed.): Denmark - DMI Historical Climate Data Collection 1768-2018, DMI Report 19-02, DMI, Copenhagen, Denmark, 2019.

Clausen, H. B. and Hammer, C. U.: The Laki and Tambora eruptions as revealed in Greenland ice cores from 11 locations, Ann. Glaciol., 10, 16-22, https://doi.org/10.3189/S0260305500004092, 1988.

Cremaschi, M.: Paleosols and Ventusols in the Central Po Plain (Northern Italy), A Study in Quaternary Geology and Soil Development, Unicopli, Milano, Italy, 1987.

Dallmayr, R., Goto-Azuma, K., Kjær, H. A., Azuma, N, Takata, M., Schüpbach, S., and Hirabayashi, M.: A High-Resolution Continuous Flow Analysis System for Polar Ice Cores, Bull. Glaciol. Res., 34, 11-20, https://doi.org/10.5331/bgr.16R03, 2016.

Darby, D. A.: Kaolinite and other clay minerals in Arctic Ocean sediments, J. Sediment. Res., 45, 272279, https://doi.org/10.1306/212F6D34-2B24-11D78648000102C1865D, 1975.

De Angelis, M., Steffensen, J. P., Legrand, M., Clausen, H., and Hammer, C.: Primary aerosol (sea salt and soil dust) deposited in Greenland ice during the last climatic cycle: Comparison with East Antarctic records, J. Geophys. Res., 102, 26681-26698, https://doi.org/10.1029/97JC01298, 1997.

Dee, D. P., Uppala, S. M., Simmons, A. J., Berrisford, P., Poli, P., Kobayashi, S., and Vitart, F.: The ERA-Interim reanalysis: Configuration and performance of the data assimilation system, Q. J. Roy. Meteor. Soc., 137, 553-597, https://doi.org/10.1002/qj.828, 2011.

Deer, F. R. S., Howie, R. A., and Zussman, J.: An Introduction to the Rock-Forming Minerals, Longman, White Plains, New York, USA, 1993.

Devi, S., Bijaksana, S., Fajar, S. J., and Santoso, N. A.: Characterization of Volcanic Ash From the 2017 Agung Eruption, Bali, Indonesia, IOP Conf. Ser.: Earth Environ. Sci., 318, 012014, https://doi.org/10.1088/1755-1315/318/1/012014, 2019.

Donarummo, J., Ram, M., and Stoermer, E. F.: Possible deposit of soil dust from the 1930's U.S. dust bowl identified in Greenland ice, Geophys. Res. Lett., 30, 1269, https://doi.org/10.1029/2002GL016641, 2003.

Drab, E., Gaudichet, A., and Jaffrezo, J. L.: Mineral particles content in recent snow at Summit (Greenland), Atmos. Environ., 36, 5365-5367, https://doi.org/10.1016/S1352-2310(02)004703, 2002.

Eyring, V., Bony, S., Meehl, G. A., Senior, C. A., Stevens, B., Stouffer, R. J., and Taylor, K. E.: Overview of the Coupled Model Intercomparison Project Phase 6 (CMIP6) experimental design and organization, Geosci. Model Dev., 9, 1937-1958, https://doi.org/10.5194/gmd-9-1937-2016, 2016.

Faure, G. and Mensing, T. M.: Isotopes, Principles and Applications, John Wiley \& Sons, USA, 2004.

Fuhrer, K., Wolff, E. W., and Johnsen, S. J.: Timescales for dust variability in the Greenland Ice Core Project (GRIP) ice core in the last 100,000 years, J. Geophys. Res., 104, 31043-31052, https://doi.org/10.1029/1999JD900929, 1999.

Genthon, C. and Armengaud, A.: GCM simulations of atmospheric tracers in the polar latitudes: South Pole (Antarctica) and Summit (Greenland) cases, Sci. Total Environ., 160-161, 101-116, https://doi.org/10.1016/0048-9697(95)04348-5, 1995.
Griffin, J. J., Windom, H., and Goldberg, E. D.: The distribution of clay minerals in the world ocean, Deep-Sea. Res., 15, 433-459, https://doi.org/10.1016/0011-7471(68)90051-X, 1968.

Grumet, N. S., Wake, C. P., Zielinski, G., Fisher, D. A., Koerner, R. M., and Jacobs, J. D.: Preservation of glaciochemical time-series in snow and ice from Penny Ice Cap, Baffin Island, Geophys. Res. Lett., 25, 357-360, https://doi.org/10.1029/97GL03787, 1998.

Han, C., Hur, S. D., Han, Y., Lee, K. Hong, S., Erhardt, T., Fischer, H., Svensson, A. M., Steffensen, J. P., and Vallelonga, P.: High-resolution isotopic evidence for a potential Saharan provenance of Greenland glacial dust, Sci. Rep., 8, 15582, https://doi.org/10.1038/s41598-018-33859-0, 2018.

Hanna, E., Fettweis, X., Mernild, S. H., Cappelen, J., Ribergaard, M. H., Shuman, C. A., Steffen, K., Wood, L., and Mote, T. L.: Atmospheric and oceanic climate forcing of the exceptional Greenland ice sheet surface melt in summer 2012, Int. J. Climatol., 34, 1022-1037, https://doi.org/10.1002/joc.3743, 2014.

Harris, I. C.: CRU JRA v2.0: A forcings dataset of gridded land surface blend of Climatic Research Unit (CRU) and Japanese reanalysis (JRA) data; Jan.1901-Dec.2018, Centre for Environmental Data Analysis, available at: https://catalogue.ceda.ac.uk/ uuid/7f785c0e80aa4df2b39d068ce7351bbb (last access: 20 June 2020), 2019.

Hurrell, J. W: NAO Index Data provided by the Climate Analysis Section, NCAR, Boulder, USA, 2003, available at: https://climatedataguide.ucar.edu/climate-data/ hurrell-north-atlantic-oscillation-nao-index-station-based, last access: 27 May 2021 (updated regularly).

Iizuka, Y., Uemura, R., Fujita, K., Hattori, S., Seki, O., Miyamoto, C., Suzuki, T., Yoshida, N., Motoyama, H., and Matoba, S.: A 60 year record of atmospheric aerosol depositions preserved in a high-accumulation dome ice core, Southeast Greenland, J. Geophys. Res., 123, 574-589, https://doi.org/10.1002/2017JD026733, 2018.

Ito, A. and Wagai, R.: Global distribution of clay-size minerals on land surface for biogeochemical and climatological studies, Sci. Data, 4, 170103, https://doi.org/10.1038/sdata.2017.103, 2017.

Kemp, S. J., Ellis, M. A., Mounteney, I., and Kender, S.: Palaeoclimatic implications of high-resolution clay mineral assemblages preceding and across the onset of the Palaeocene-Eocene thermal maximum, North Sea Basin, Clay Miner., 51, 793-813, https://doi.org/10.1180/claymin.2016.051.5.08, 2016.

Kim, H.: Global Soil Wetness Project Phase 3 Atmospheric Boundary Conditions (Experiment 1), Data Integration and Analysis System (DIAS) [data set], https://doi.org/10.20783/DIAS.501, 2017.

Kobashi, T., Kawamura, K., Severinghaus, J. P., Barnola, J.-M., Nakaegawa, T., Vinther, B. M., Johnsen, S. J., and Box, J. E.: High variability of Greenland surface temperature over the past 4000 years estimated from trapped air in an ice core, Geophys. Res. Lett., 38, L21501, https://doi.org/10.1029/2011GL049444, 2011.

Koide, M., Michel, R., Goldberg, E., Herron, M. M., and Langway, C. C.: Characterization of radioactive fallout from pre- and post-moratorium tests to polar ice caps, Nature, 296, 544-547, https://doi.org/10.1038/296544a0, 1982.

Kuramoto, T., Goto-Azuma, K., Hirabayashi, M., Miyake, T., Motoyama, H., Dahl-Jensen, D., and Steffensen, J. P.: Seasonal vari- 
ations of snow chemistry at NEEM, Greenland, Ann. Glaciol., 52, 193-200, https://doi.org/10.3189/172756411797252365, 2011.

Kurosaki, Y. and Mikami, M.: Recent frequent dust events and their relation to surface wind in East Asia, Geophys. Res. Lett., 30, 1736, https://doi.org/10.1029/2003GL017261, 2003.

Kurosaki, Y., Matoba, S., Iizuka, Y., Niwano, M., Tanikawa, T., Ando, T., Hori, A., Miyamoto, A., Fujita, S., and Aoki, T.: Reconstruction of sea ice concentration in northern Baffin Bay using deuterium excess in a coastal ice core from the northwestern Greenland Ice Sheet, J. Geophys. Res.-Atmos., 125, e2019JD031668, https://doi.org/10.1029/2019JD031668, 2020.

Lambert, F., Delmonte, B., Petit, J. R., Bigler, M., Kaufmann, P. R., Hutterli, M. A., Stocker, T. F., Ruth, U., Steffensen, J. P., and Maggi, V.: Dust-climate couplings over the past 800,000 years from the EPICA Dome C ice core, Nature, 452, 616-619, https://doi.org/10.1038/nature06763, 2008.

Legrand, M. and Mayewski, P.: Glaciochemistry of polar ice cores: A review, Rev. Geophys., 35, 219-243, https://doi.org/10.1029/96RG03527, 1997.

Lupker, M., Aciego, S. M., Bourdon, B., Schwander, J., and Stocker, T. F.: Isotopic tracing ( $\mathrm{Sr}, \mathrm{Nd}, \mathrm{U}$ and $\mathrm{Hf}$ ) of continental and marine aerosols in an 18th century section of the Dye3 ice core (Greenland), Earth Planet. Sc. Lett., 295, 277-286, https://doi.org/10.1016/j.epsl.2010.04.010, 2010.

Maggi, V.: Mineralogy of atmospheric microparticles deposited along the Greenland Ice Core Project ice core, J. Geophys. Res., 102, 26725-26734, https://doi.org/10.1029/97JC00613, 1997.

Matoba, S., Narita, H., Motoyama, H., Kamiyama, K., and Watanabe, O.: Ice core chemistry of Vestfonna Ice Cap in Svalbard, Norway, J. Geophys. Res., 107, 4721, https://doi.org/10.1029/2002JD002205, 2002.

Matoba, S., Motoyama, H., Fujita, K., Yamasaki, T., Minowa, M., Onuma, Y., Komuro, Y., Aoki, T., Yamaguchi, S., Sugiyama, S., and Enomoto, H.: Glaciological and meteorological observations at the SIGMA-D site, northwestern Greenland Ice Sheet, Bull. Glaciol. Res., 33, 7-14, https://doi.org/10.5331/bgr.33.7, 2015.

Mayewski, P. A., Meeker, L. D., Twickler, M. S., Whitlow, S., Yang, Q., Lyons, W. B., and Prentice, M.: Major features and forcing of high-latitude northern hemisphere atmospheric circulation using a 110,000-year-long glaciochemical series, J. Geophys. Res., 102, 26345-26366, https://doi.org/10.1029/96JC03365, 1997.

Mudroch, A., Zeman, A. J., and San, R.: Identification of mineral particles in fine grained lacustrine sediments with transmission electron microscope and $\mathrm{x}$-ray energy dispersive spectroscopy, J. Sediment. Petrol., 47, 244-250, https://doi.org/10.1306/212F713F-2B24-11D78648000102C1865D, 1977.

Mueller, J. P. and Bocquier, G.: Dissolution of kaolinites and accumulation of iron oxides in lateritic-ferruginous nodules: Mineralogical and microstructural transformations, Geoderma, 37, 113-116, https://doi.org/10.1016/0016-7061(86)90025-X, 1986.

Nagatsuka, N., Takeuchi, N., Uetake, J., and Shimada, R.: Mineralogical composition of cryoconite on glaciers in northwest Greenland, Bull. Glaciol. Res., 32, 107-114, https://doi.org/10.5331/bgr.32.107, 2014.

Nagatsuka, N., Matoba, S., Kadota, M., Fujita, K., Tsushima, A., Dallmayr, R., Hirabayashi, M., Ogata, J., Ogawa-Tsukagawa, Y., and Goto-Azuma, K.: Stable isotope, ion concentrations, and mineral dust data from northwestern Greenland ice core (SIGMA-D), 1.00, Arctic Data archive System (ADS) [data set], Japan, https://doi.org/10.17592/001.2021052501, 2021.

Nahon, D. B.: Introduction to the Petrology of Soils and Chemical Weathering, John Wiley, New York, 1991.

Onuma, Y. and Kim, H.: MIROC6 model output prepared for CMIP6 LS3MIP land-hist, Version 20200423, Earth System Grid Federation [data set], https://doi.org/10.22033/ESGF/CMIP6.5622, 2020a.

Onuma, Y. and Kim, H.: MIROC6 model output prepared for CMIP6 LS3MIP land-hist-cruNcep, Version 20200918, Earth System Grid Federation [data set], https://doi.org/10.22033/ESGF/CMIP6.5627, 2020b.

Onuma, Y. and Kim, H.: MIROC6 model output prepared for CMIP6 LS3MIP land-hist-princeton, Version 20200918, Earth System Grid Federation [data set], https://doi.org/10.22033/ESGF/CMIP6.5628, 2020c.

Onuma, Y. and Kim, H.: MIROC6 model output prepared for CMIP6 LS3MIP land-hist-wfdei, Version 20200727, Earth System Grid Federation [data set], https://doi.org/10.22033/ESGF/CMIP6.5629, 2020d.

Oyabu, I., Matoba, S., Yamasaki, T., Kadota, M., and Iizuka, Y.: Seasonal variations in the major chemical species of snow at the South East Dome in Greenland, Polar Sci., 10, 36-42, https://doi.org/10.1016/j.polar.2016.01.003, 2016.

Pallister, J. S., Hoblitt, R. P., and Reyes, A. G.: A basalt trigger for the 1991 eruptions of Pinatubo volcano?, Nature, 356, 426-428, https://doi.org/10.1038/356426a0, 1992.

Parvin, F., Seki, O. Fujita, K., Iizuka, Y., Matoba, S., and Ando, T.: Assessment for paleoclimatic utility of biomass burning tracers in SE-Dome ice core, Greenland, Atmos. Environ., 196, 86-94, https://doi.org/10.1016/j.atmosenv.2018.10.012, 2019.

Petit, J. R., Mounier, L., Jouzel, J., Korotkevich, Y. S., Kotlyakov, V. I., and Lorius, C.: Palaeoclimatological and chronological implications of the Vostok core dust record, Nature, 343, 56-58, https://doi.org/10.1038/343056a0, 1990.

Pye, K.: Aeolian Dust and Dust Deposits, Academic, San Diego, USA, 1987.

Ram, M. and Koenig, G.: Continuous dust concentration profile of pre-Holocene ice from the Greenland Ice Sheet Project 2 ice core: Dust stadials, interstadials and the Eemian, J. Geophys. Res., 102, 26641-26648, https://doi.org/10.1029/96JC03548, 1997.

Ruth, U., Wagenbach, D., Steffensen, J. P., and Bigler, M.: Continuous record of microparticle concentration and size distribution in the central Greenland NGRIP ice core during the last glacial period, J. Geophys. Res., 108, 4098, https://doi.org/10.1029/2002jd002376, 2003.

Schüpbach, S., Fischer, H., Bigler, M., Erhardt, T., Gfeller, G., Leuenberger, D., Mini, O., Mulvaney, R., Abram, N. J., Fleet, L., Frey, M. M., Thomas, E., Svensson, A., Dahl-Jensen, D., Kettner, E., Kjaer, H., Seierstad, I., Steffensen, J. P., Rasmussen, S. O., Vallelonga, P., Winstrup, M., Wegner, A., Twarloh, B., Wolff, K., Schmidt, K., Goto-Azuma, K., Kuramoto, T., Hirabayashi, M., Uetake, J., Zheng, J., Bourgeois, J., Fisher, D., Zhiheng, D., Xiao, C., Legrand, M., Spolaor, A., Gabrieli, J., Barbante, C., Kang, J.-H., Hur, S. D., Hong, S. B., Hwang, H. J., Hong, S., Hansson, M., Iizuka, Y., Oyabu, I., Muscheler, R., Adolphi, F., Maselli, O., McConnell J., and Wolff, E. W.: Green- 
land records of aerosol source and atmospheric lifetime changes from the Eemian to the Holocene, Nat. Commun., 9, 1476, https://doi.org/10.1038/s41467-018-03924-3, 2018.

Severin, K. P.: Energy dispersive spectrometry of common rock forming minerals, Kluwer Academic Publishers, Dordrecht, the Netherlands, 2004.

Sheffield, J., Goteti, G., and Wood, E. F.: Development of a 50Year High-Resolution Global Dataset of Meteorological Forcings for Land Surface Modeling, J. Climate, 19, 3088-3111, https://doi.org/10.1175/JCLI3790.1, 2006.

Simonsen, M. F., Baccolo, G., Blunier, T., Borunda, A., Delmonte, B., Frei, R., Goldstein, S., Grinsted, A., Kjær, H. A., Sowers, T., Svensson, A., Vinther, B., Vladimirova, D., Winckler, G., Winstrup, M., and Vallelonga, P.: East Greenland ice core dust record reveals timing of Greenland ice sheet advance and retreat, Nat. Commun., 10, 4494, https://doi.org/10.1038/s41467-019-125462, 2019.

Steffensen, J.: The size distribution of microparticles from selected segments of the Greenland Ice Core Project ice core representing different climatic periods, J. Geophys. Res., 102, 26755-26763, https://doi.org/10.1029/97JC01490, 1997.

Stein, A. F., Draxler, R. R., Rolph, G. D., Stunder, B. J. B., Cohen, M. D., and Ngan, F.: NOAA's HYSPLIT Atmospheric Transport and Dispersion Modeling System, B. Am. Meteorol. Soc., 96, 2059-2077, https://doi.org/10.1175/BAMS-D-14$00110.1,2015$.

Svensson, A., Biscaye, P. E., and Grousset, F. E.: Characterization of late glacial continental dust in the greenland ice core project ice core, J. Geophys. Res., 105, 4637-4656, https://doi.org/10.1029/1999JD901093, 2000.

Tatebe, H., Ogura, T., Nitta, T., Komuro, Y., Ogochi, K., Takemura, T., Sudo, K., Sekiguchi, M., Abe, M., Saito, F., Chikira, M., Watanabe, S., Mori, M., Hirota, N., Kawatani, Y., Mochizuki, T., Yoshimura, K., Takata, K., O’ishi, R., Yamazaki, D., Suzuki, T., Kurogi, M., Kataoka, T., Watanabe, M., and Kimoto, M.: Description and basic evaluation of simulated mean state, internal variability, and climate sensitivity in MIROC6, Geosci. Model Dev., 12, 2727-2765, https://doi.org/10.5194/gmd-122727-2019, 2019.

Taylor, H. E. and Lichte, F. E.: Chemical composition of Mount St. Helens volcanic ash, Geophys. Res. Lett., 7, 949-952, https://doi.org/10.1029/GL007i011p00949, 1980.

Uppala, S. M., Kallberg, P. W., Simmons, A. J., Andrae, U., daCosta Bechtold, V., Fiorino, M., Gibson, J. K., Haseler, J., Hernandez, A., Kelly, G. A., Li, X., Onogi, K., Saarinen, S., Sokka, N., Allan, R. P., Andersson, E., Arpe, K., Balmaseda, M. A., Beljaars, A. C. M., van de Berg, L., Bidlot, J., Bormann, N., Caires, S., Chevallier, F., Dethof, A., Dragosavac, M., Fisher, M., Fuentes, M., Hagemann, S., Holm, E., Hoskins, B. J., Isaksen, L., Janssen, P. A. E. M., Jenne, R., McNally, A. P., Mahfouf, J. F., Morcrette, J. J., Rayner, N. A., Saunders, R. W., Simon, P., Sterl, A., Trenberth, K. E., Untech, A., Vasiljevic, D., Viterbo, P., and Woollen, J.: The ERA-40 Reanalysis, Q. J. Roy. Meteor. Soc., 131, 29613012, https://doi.org/10.1256/qj.04.176, 2005.

Újvári, G., Stevens, T., Svensson, A., Klötzli, U. S., Manning, C., Németh, T., Kovaìcs, J., Sweeney, M. R., Gocke, M., Wiesenberg, G. L. B., Markovic, S. B., and Zech, M.: Two possible source regions for central Greenland last glacial dust, Geophys. Res. Lett., 42, 10399-10408, https://doi.org/10.1002/2015GL066153, 2015.

van den Broeke, M., Bamber, M. J., Ettema, J., Rignot, E., Schrama, E., van de Berg, W. J., van Meijgaard, E., Velicogna, I., and Wouters, B.: Partitioning recent Greenland mass loss, Science, 326, 984-986, https://doi.org/10.1126/science.1178176, 2009.

van den Hurk, B., Kim, H., Krinner, G., Seneviratne, S. I., Derksen, C., Oki, T., Douville, H., Colin, J., Ducharne, A., Cheruy, F., Viovy, N., Puma, M. J., Wada, Y., Li, W., Jia, B., Alessandri, A., Lawrence, D. M., Weedon, G. P., Ellis, R., Hagemann, S., Mao, J., Flanner, M. G., Zampieri, M., Materia, S., Law, R. M., and Sheffield, J.: LS3MIP (v1.0) contribution to CMIP6: the Land Surface, Snow and Soil moisture Model Intercomparison Project - aims, setup and expected outcome, Geosci. Model Dev., 9, 2809-2832, https://doi.org/10.5194/gmd-9-2809-2016, 2016.

Velde, B.: Origin and Mineralogy of Clays: Clays and Environment, Springer-Verlag, New York, 1995.

Weedon, G. P., Balsamo, G., Bellouin, N., Gomes, S., Best, M. J., and Viterbo, P.: The WFDEI meteorological forcing data set: WATCH Forcing Data methodology applied to ERA Interim reanalysis data, Water Resour. Res., 50, 7505-7514, https://doi.org/10.1002/2014WR015638, 2014.

Whitlow, S., Mayewski, P. A., and Dibb, J. E.: A comparison of major chemical species seasonal concentration and accumulation at the South Pole and Summit, Greenland, Atmos. Environ., 26A, 2045-2054, https://doi.org/10.1016/0960-1686(92)900894, 1992.

Wilson, T. R. S.: Salinity and the major elements of sea water, Chap. 6, in: Chemical Oceanography, 2nd edn., edited by: Riley, J. P. and Skirrow, G., Academic Press, Orland, 1, 365-413, 1975.

Woollings, T., Hannachi, A., Hoskins, B., and Turner, A.: A regime view of the North Atlantic Oscillation and its response to anthropogenic forcing, J. Climate, 23, 1291-1307, https://doi.org/10.1175/2009JCLI3087.1, 2010.

Wu, G., Zhang, X., Zhang, C., and Xu, T.: Mineralogical and morphological properties of individual dust particles in ice cores from the Tibetan Plateau, J. Glaciol., 62, 46-53, https://doi.org/10.1017/jog.2016.8, 2016.

Yokoo, Y., Nakano, T., Nishikawa, M., and Quan, H.: Mineralogical variation of $\mathrm{Sr}-\mathrm{Nd}$ isotopic and elemental compositions in loess and desert sand from the central Loess Plateau in China as a provenance tracer of wet and dry deposition in the northwestern Pacific, Chem. Geol., 204, 45-62, https://doi.org/10.1016/j.chemgeo.2003.11.004, 2004.

Zhang, P., Jeong, J. H., Yoon, J. H., Kim, H., Wang, S. Y. S., Linderholm, H. W., Fang, K., Wu, X., and Chen, D.: Abrupt shift to hotter and drier climate over inner East Asia beyond the tipping point, Science, 370, 1095-1099, https://doi.org/10.1126/science.abb3368, 2020. 